\title{
PLANNING FOR WILDLIFE IN THE UNITED STATES \\ $\bullet$
}

\section{PART IX}

OF THE
SUPPLEMENTARY REPORT OF THE LAND PLANNING COMMITTEE TO THE

NATIONAL RESOURGES BOARD 


\section{SUPPLEMENTARY REPORT OF THE LAND PLANNING COMMITTEE TO THE NATIONAL RESOURCES BOARD}

\section{Published in eleven separate parts}

Part I. General Conditions and Tendencies Influencing the Nation's Land Requirements

PArt II. Agricultural Exports in.Relation to Land Policy

PART III. Agricultural Land Requirements and Available Resources

Part IV. Land Available for Agriculture Through Reclamation

Part V. The Problem of Soil Erosion

PART VI. Maladjustments in Land Use

Part VII. Certain Aspects of Land Problems and Government Land Policies

Part VIII. Forest Land Resources, Requirements, Problems, and Policy

PART IX. Planning for Wildlife in the United States

Part X. Indian Land Tenure, Economic Status, and Population Trends

PART XI. Recreational Use of Land in the United States

From the collection of the

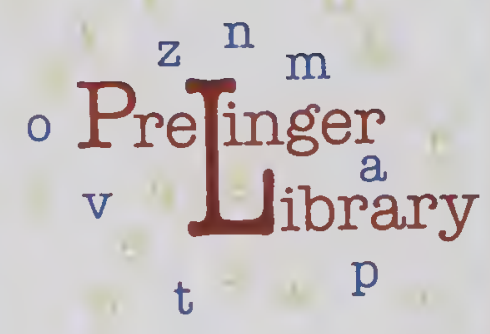

San Francisco, California

2008 


\title{
PLANNING FOR WILDLIFE IN THE UNITED STATES
}

\author{
PART IX \\ OF THE \\ REPORT ON LAND PLANNING \\ AND TIE FOREST SERVICE, DEPARTMENT OF AGRICULTURE \\ FOR TIIE \\ LAND PLANNING COMMITTEE OF THE NATIONAL RESOURCES BOARD
}

The National Resources Board assumes no responsibility for the view's and oplnions expressed herein 
$$
\text { , }
$$ 
On November 2S, 1934, the National Resonrees Board submitted to the President, in accordance with an Executive order, its report on National Planning and Public Works in Relation to Natural Resources and Including Land Use and Water Resonrees. Part II of that report was the Report of the Land Planning Committee. In the conrse of preparing part II of the above report a liarge volume of basic data and information was collected which conld not then be inchuded. 'The publication of the present report is for the purpose of making such data and information available to interested persons and organizations.

The present land report has been organized into 11 parts aceording to subject matter and the contributing agencies. These 11 parts are made arailable as 11 separate publications. Organization and publication on this basis was done because many persons and agencies are interested only in certain parts of the present report, and the neeessity of purchasing the whole report in order to obtain the desired part or parts is thereby eliminated.

The present land report, when conceived as a whole, does not purport to be a complete work on the subject of land utilization, or of its related problems and proposed lines of action; neither is it designed to be a thoroughly integrated piece of work. The primary aim here las been to set forth the facts, analyses, and the recommended lines of action as developed by each of the varions eontributing govermmental bureaus, divisions, sections, or individuals, on the problems with which each of such agencies or persons is eoncerned. The points of view are, therefore, those of the contributing agencies or indiriduals themselves. The Land Planning Committee presents the report as information, but assumes no responsibility for the opinions expressed in it.

This report was prepared under the direction of Dr. L. C. Gruy, director of the Land Section of the National Resourees Board, aided by John B. Bennett, who served as administrative assistant and as secretary to the Land Planning Committee. Editing and preparation of the report for publication were under the direction of $\mathrm{Mr}$. H. H. Erdmann, agricultural economist of the Land Section, National Resourees Board.

Authorship by ageneies and individuals is acknowledged in their respective eontributions. The following governmental agencies have contributed to the whole report: The Geological Surver, the Dirision of Grazing Control, the Office of Indian Affairs, the National Park Serviee, and the Bureau of Rechanation, in the United States Department of the Interior; and the Bureau of $A g r i e u l t u r a l$ Engineering, the Biological Surver, the Bureau of Chemistry and Soils, the Forest Service, the Soil Conservation Service, the Weather Burean, the Divisions of Land Ecouomies, of Farm Management and Costs, and of Farm Finance in the Bureau of Agricultural Eeonomies, and the Land Policy Section, the Production Planning Section, the Import-Export Section, and the Agrieultural-Industrial Relations Section of the Division of Program Planning of the Agrieultural Adjustment Administration in the United States Department of Agrieulture. Credit also is due to the State agricultural experiment stations and extension services, State planning bourds, commissions, and other State organizations and individuals for aid in preparation of sereral sections of the report.

Land Plaming Committee

Oscar Chapuas.

IV. G. MeNineNhall.

H. H. BeNnetT.
MI. L. Wilsox, Chairman.

Mordecai Ezekiel.

JACOB BAKER.

Charles W. Hliot, 2D.

L. C. Gray, Director. 



\section{LA N D R E Q UIREM E N T A N D POLICIES WITH RESPECT T O W I L D L I F E}

\section{Contents}

Preface

Section I. Requirements for Wildlife Areas

Economic importance of wildlife-Social and recreational importance-Need of wildlife managementPossibilities and limitations in associating wildlife with other uses of land-Public areas employed as specialized refuges-Public areas desiguated as refuges but deroted to other major uses-Public areas needed for specialized refuges-Public areas in other uses that should be designated as wildlife refuges-Private lands employed as a habitat for wildlife.

Section II. Policies With Respect to Wildlife

Areas now in public ownership devoted to wildlife--Programs of aequisition; suggestions for modification--Integration of Federal and State policies--Enconraging game production on private lands.

Section III. Wildlife Management in National Forests

Encouraging game management on public land in other use- Economie and social values of wildife areas-Wildlife and other land uses-Areas suitable only for refuges-Areas specially adapted to wildlife-.. Areas available for wildlife-Needed additions to forests--Prisately owned land as a hibitat for wildlife. 



\section{REQUIREM ENTS FOR WILDLIFE AREA *}

\section{Economic Importance of Wildlife}

Wildlife is as essentially a product of land (or land and water) as is timber, agricultural crops, or domestic livestoek. A multitude of kinds, bearing importantly upon liuman welfare, are especially adapted to various kinds of habitat, from dense forest and open range to cultivated fields, water, and marsh. It follows, therefore, that wildlife cannot be ignored in any comprehensive, well-considered plan for land utilization. Mammals, birds, fishes, and other wild vertebrates constitute a major national resouree that is becoming more generally appreciated, as evidenced by increasing interest in every phase of nature study.

Mlany of the various forms, fur bearers and fishes especially, are of direct economic value. An example is the income derived from the sale of hunting, trapping, and fishing licenses; the furs of course have a great commercial ralue also, and in some cases the meat supplies a lighly prized form of food. That the meat and fur value of wild mammals and birds is considerable is indicated by an estimated total for 1 year of more than $\$ 190,000,000$ for the whole country. Capitalized on a low-pereentage basis the total value of wildlife would far exceed $\$ 1,000,000,000$. Other economic values are receipts from the sale of hunting and fishing equipment, including guns, ammunition, fishing tackle, and clothing, expenditures of sportsmen Ior transportation, board, hire of guides, and for hunting and fishing privileges on private lands. To the foregoing may be added the output of the fur trade, including the lur manufacturing industry, the annual expenditures for the maintenance of the numerous and widely distributed hunting and fishing clubs; also the general expenses of tourists and others attraeted primarily by an abundance of wildlife. It is these various wildlife ralues that go to make up the estimated grand total of at least $\$ 1,000$,000,000 annually.

Last but not least should be mentioned the incalculable value of wildlife, ehiefly birds, as destroyers of the insects that prey on agricultural crops and forest trees.

\section{Social and Recreational Importance}

The social values also, including the recreational and educational advantages arising from an abundance of wildlife in general, are more intangible and therefore more difficult to appraise than the economic values, but they are none the less real.

\footnotetext{
- Contributed by the Bureau of Biological Survey.
}

In Europe from time immemorial hunting has been a sport restricted mainly to the nobility or the wealthy classes, who usually assume direct ownership of all game ranging on their large estates. In America, on the other hand, the traditional concept is that ownership of most game, whether on prirately owned or public land, is rested in the State or the Federal Gorermment, and that bunting, subject to restrictive laws and regulations, including those in regard to trespass, is for all who wish to indulge in it. The relative freedom of the Amerienn srstem is due to the fact that for the early settlers the pursuit and killing of game and fur bearers was a rital necessity in providing meat for food and furs for clothing. The skilled hunter became an expert marksman who defended his home and gave an excellent account of himself in early military campaigns. The role of the hunter, important first in gaining a livelihood, led naturally through successive generations to the development of a love of the chase as sport. The joy of the chase provides wholesome recreation of a kind that can be obtained in no other way, and one that perhaps only a hunter can fully appreciate. The many different kinds of lunting for large and small game and the several kinds of fishing afford the variety adapted to the need and inelination of the various elasses of our growing population. The pursuit of large game, especinlly, which often requires persistent effort as well as skill, tends to bring out qualities contributing to the virility of the race.

A considerable number to whom the taking of animal life is repugnant, satisfy a natural urge for contact with primitive nature by stalking wildlife to obtain photographs at short range, or to make detailed studies of the life habits of the several species.

A report of the Senate Committee on Conservation of Wildlife Resourees (S. Rept. 1329, 71st Cong.), estimates that there was during the deeade ending in 1930 a 400 -percent increase in the number of people who enjoy the pastimes of hunting and fishing. It estimates the number of licensed hunters in the United States in 1929 at $7,000,000$ and the total of all hunters and fishermen at probably $13,000,000$. The eurrent trend toward shorter hours and fewer working days should add tremendously to the number of men who seek such out-door recreation.

Hunting and fishing as a sport attract men to the forest and mountains, the lakes, and the streams, where for a brief perior they may escape the artificial life to which by modern conditions most are eonfined. 
From such an outing they return to their usual duties improred mentally and physically, with a broadened outlook and a quickened appreciation of natural resources that should contribute immensurably to the wealth, comfort, and well-being of the people.

\section{Need of Wildlife Management}

Consercation Alone Not the Solution: Recognition of wildlife as a national asset of major importanee brings into relief the problem of manngement. Nuch has been written on the conservation of wildlife by autlors representing many shades of opinion, but comparatirely little indicating a broad, elear coneept of its corollary, wildlife management. The emphasis on conservation has doubtless been due to the necessity of building up a militant opposition to destructive forces leading toward the extermination of so many species. In many directions this danger is not yet past, but conservation should be recognized in its true relation as a means to an end and not an end in itself. The overabundance of game in one region may present a more pressing and difficult problem than would its absence or scarcity in another. Game management consists largely in the regulation of numbers in accordance with food supply and cover, with due regard for other local interests.

At the time of the discovery of North America, its wildlife, probably unequaled elsewhere in diversity and abundance, ranged in every kind of habitat throughout the length and breadth of the continent. Great herds of grass-feeding animals-buffalo, antelope, elk, and mountain sheep-occupied the open plains or high mountains of the West. Moose and earibou had an extensive range in the northern forests, and bears were numerous wherever conditions were suitable. Fur bearers in great variets, including the beaver, otter, wolverine, marten, mink, fox, raccoon, and muskrat, were widely distributed and soon became the basis of an extensive and profitable pioneer industry. Lpland game birds, as wild turkers, passenger pigeons in amazing numbers, and the various kinds of grouse and prairie ehickens, occupied great areas adapted to their dirergent needs. Watcrfowl in countless millions, especially ducks, geese, and swans, nested orer an enormous territory but particularly in the rast prairie regions of the Middle West, the Northwest, and areas extending into Canada and Alaska; and in concentrated myriads migrated southward to winter. Many writers attest to their ahmost incredible abundance.

For example, Grinnell records that in Eastern and Hogg Bay, Chesapeake Bay, one might see redheads rafted in bodies miles in extent, probably not less than 50,000 ducks in a mass. ${ }^{2}$ Incidentally the redhead is now so reduced in numbers that only special protection will prevent its extermination. Geese also were in such

\footnotetext{
2 Grinnel], G. B. AMERTCan Duck Shooting. New York, 1901, pp. 485-86.
}

abundance that, especially in California, they became destructive to winter wheat on a large scale.

Previous to the arrival of the settlers, the scattered Indian population, hunting mainly with bows and arrows, and without effective tools, was negligible in its effeet upon the game. Predatory animals wolves, mount ain lions, bobeats, and, in the West, coyotes-took their toll, but there was ample food for all.

Essentials of Wildlife Management: A review of the general field, and contrast with past abundance, shows that wildlife has nearly everywhere been sadly neglected as a national resource or grossly mismanaged. The essentials of wildlife management are relatively simple but exceedingly difficult to put into effect, owing to public apathy, sheer ignorance or misunderstanding, selfishness, misguided sentiment, and polities.

First of all, only a well-informed publie opinion can overeome the inertia and prejudice that tend to paralyze constructive effort. The management of game, and of wildlife as a whole, calls for professional skill of the highest order. The wildhife administrator should combine broad teehnical knowledge and the instinets of a naturalist with eapacity for dealing with hard, factual realities. Such a combination of qualities is not easily obtained, and it is rare where game officials are appointed merely as a reward for political party services. Occasionally a political appointee will derelop some capacity as a game manager, but by the time he has become familiar with the intricacies of the work his services are apt to be terminated. His political successor may be sincere, but untrained, and the splendid game assets suffer for lack of the attention that can be giren only by those who would make wildlife management a career. In order to function properly, game commissions should be composed of well-informed individuals, free from political pressure, and must have authority to denl promptly and effectirely with rapidly changing conditions as they arise.

The adequate management of big game on national forests ${ }^{3}$ is urgently needed and presents especial difficulty owing to conflicting views with regard to jurisdiction. Game is a product of the forest, and too abundant game on national forests may be destruetive to forest reproduction and may seriously interfere with the proper regulation there of the grazing of domestic stock. Proper game management calls for the regulation of numbers, ordinarily by hunting under a limited license plan, the game supply to be maintained with due regard to range-carrying eapacity and other loeal interests. The game should be fostered and made to rield an annual crop that will be harvested in an orderly way adapted to local conditions.

Some States may have what is regarded as competent game administration, but it is obviously impossible

\footnotetext{
3 See also contribution by the Forest Service on rildife management on national
} forests. Sec. III of part IX. 
for them, subject as they are to clianging policies and political expedieney, to equal the efficiency of the wildlife service that can be extended to national forests by the Federal Government under plans coordinating all forest uses.

\section{Possibilities and Limitations in Associating Wildlife with Other Uses of Land}

Wildlife in a multiplicity of forms has a more or less direct bearing upon land uses nearly everywhere. Certain kinds may be highly benefieial, others neutral, or some may seriously interfere with economic utilization of lands. Crows, for example, are beneficial in consuming grubs or eutworms that injure agricultural crops, but they destroy many eggs of wild ducks, the breeding of which constitutes a highly important form of marshland utilization. And these differing crow activities may be carried on orer elosely arljoining lands.

Competitors with Wildlife for Land: With the appearance of the settlers, the clearing of the forests for farms and town sites, the occupation of grasslands for agricultural purposes, or the grazing of domestic stock, the general aspect of much of the former domain of willlife was transformed. As the tide of eivilization and general land occupation moved westward across the continent the greater part of the plains animals either were wiped out or resorted to the forests, which are the great reservoirs of so much of our remaining upland game. Though deplorable, the displicement of much of the gane was inevitable. The final passing of the buffalo on open ranges coukd not have been prevented, for great herds of buflialo have no place, as game, under modern conditions. Inevitable also was the passing of most of the antelope, originally more numerous perhaps than the buffalo.

The intensive settlement of the vast prairie areas of the Niddle West and north into Canada, and the derelopment of one of the great test grain-producing regions in the workd, led directly to the virtual elimination of linge sections of the best breeding ringes of our most inportant waterfowl. The surface absorption of moisture by the cultivation of land, and the deliberate drainage of so many of the originally innumerable ponds, lakes, and marslıes, have wiped out most of the local waterfowl breeding grounds. Another serious result has been the lowering of underground water levels, shown in the failure of wells, the drying up of springs that should feed streams, and the generul desiceation of the country. Neanwlide many of the lands drained have proved to be of little agriculturil value, and during periods of drought wind erosion has strongly tended to complete the picture of desolation.

Restoration Measures Attempted: Efliorts are now being made to restore some of the $\$ 4,000,000$ acres that have been drained in the comntry as a whole; and yet drainage engineers may in many loculities be continuing the destructive policy of the past.

All drainage projects of the Reclamation Service should be serutinized with a view to determining their effect upon the native wildlife and other water uses and values, and these should be balanced against their prospective value for the purposes already planned

Pressure on wildlife by human occupation of the land, therefore, together with almost unrestricted killing by lunters, inroads by predatory nnimals, and other incidental factors, has led to the disappearance of game of many kinds or to its reduction to compuratively small numbers over most of its former range. In the Eastern States the larger predatory animals virtually disappeared many years ago along with the larger game, but the destruetion of game by the mountain lions, wolves, coyotes, and bobeats that still remain in the Western States continues on a seale that is not generally realized. The greatest predatory animal after all, however, is man. Control must be exereised over the too indiscriminate use of modern firearms by the inereasing millions of hunters, if a sufficient breeding stock of game is to be maintained. This does not mean that hunting under proper conditions should be discouraged, but rathes that its implications slould be realized and that it should be carried on and regulated as a game-cropl harvesting operation.

Although the general outlook for forms of wildlife lounted as game may seem discouraging, conservation progress is being made and much may yet be done through the properly coordinated use of land, not only to save the remmants, but greatly to inerease numbers and restore game to vast sections from which it has been eliminated. To deal intelligently with the problem requires an appreciation of the requirements of the game and of all the factors that may result in decreases or increases in numbers of wildlife forms. With these requirements elearly in mind wildlife values should be measured against land values for other uses every were.

Forest Wildlife: The fact that the forests are the great reservoirs of most of our upland game leads logically to a consideration of the relation of forestry to gane conservation with a riew to the best use of forest lands." Since the maximum production of timber tends to conflict with the maximum production of game, the redative economic and social ralues and all the fuctors involved should be carefully woighed in connection with general forest management. Forest reproduction is so unsatisfactory in many places, from the forester's standpoint, that planting has to be resorted to. In such projeets of forest restoration the probable trend in future comparative values of timber and game should be anticipated as far as possible. These comparative ralues, difficult to measure, will vary with many local conditions. The rapid substitution of other nore durable

- Seo also contribution by the Forest stervice un wildlife manakement on nutional forests. (Sec. Ill of part 1.X.) 
materials for the wood that was formerly used in construetion of all kinds, and the slow growth of mereliantable timber suggests that in planting operations the potential values of wildlife as well as of timber values should be given consideration.

Large game animals, as well as beavers, porcupines, rabbits, and other smaller forms, are apt to become too alundant and destructive to the forest. In places the competition between unregulated game and domestic stock for forage has become acute and the range permanently impaired. Serious problems thus tend to arise.

II ilderness Preservation and Restoration: Conditions even approximating the primeval wilderness ean hardly be maintained anywhere unless the areas available are extensive. Wilderness, or natural, areas typical of the prineipal linds of land surface and landseape aspect, ineluding humid and arid, forested and unforested, should be preserved in the various parts of the country for values that cannot readily be ineasured in dollars and cents. The fauna is dependent upon the flora, and typical samples of both should be perpetuated. Such a plan contemplates, as examples, the setting aside for posterity of suitable tracts of such divergent character as the great forest of the Olympie Peninsula of Washington, the Everglades of Florida, and the giant eactus desert of southern Arizona. The areas should to well-rounded units and include, as far as possible, both summer and winter range for game, and should function as wildlife preserves of the highest trpe. In such areas modifying human influences should be limited to such emergeney measures as fire and flood control and the reduction of excessive numbers of large game and predatory animals. Suitably distributed wilderness or natural areas should be maintained in the national forests; several in the larger national parks might be so designated, and others might be carved from the unreserved public domain. It is probable that few typieal areas of the long-grass and short-grass prairies that played so prominent a part in our national development remain unmodified, but some might be restored to an approximation of their original condition. As such, and supporting suitable wildlife, they would be of surpassing interest to posterity. Some suitable prairie areas would probably have to be acquired by purchase.

The present limited system of refuges, Federal and State, designed for the perpetuation of particular species, as the buffalo, should be extended to provide more amply for other animals, including the antelope, valley elk of California, the peceary, and others.

Human capacity to transform the land surface and to render it unfit for habitation by wildlife, especially game, has been clearly demonstrated. That a reversal of the destructive process can bring about an amazing restoration of game has also been amply attested. It follows then, that in manipulation of the environment, game should be given due consideration as a natural resource in all plans for land utilization. Game must be subject to appropriate control measures, but it will often be found highly profitable to encourage its production along with other land uses.

Relations of Big Game, Predators, and Lirestock: Large game animals, as deer, antelope, and elk, often compete directly with domestic stock for forage. To maintain the food-produeing eapacity of a given area may require a reduetion in the numbers of eitler or both. Adjustment of the conflicting interests of game and the grazing of domestie stock, and the relation of botl to predatory animals, is a complieated problem on the national forest and the publie domain. Organized predatory animal-control operations are carried on by the Federal Government, largely on national forest areas and the public domain but also on State and private holdings in cooperation with the States. The direct objective is the protection of the domestic stock for which grazing fees on the national forest are collected by the Forest Service. The work is financed jointly by the Federal Government, which through the Biological Survey is charged with the direction; and the States or stoek associations, which furnish the larger share of the funds required. This seems an equitable arrangement, as the States are hearily interested in the stoek industry both on and off the forest, while the Government is the principal landowner. But the same national forests are the prineipal reservoirs of our larger game, especially deer, and a heavy toll is normally taken every year by mountain lions, coyotes, and bobeats. While mountain lions are the more notorious deer slayers, each year killing great numbers of deer in sections where abundant, the inroads of coyotes, especially on fawns and the smaller game species, are usually more serious, owing to the greater number of these wild members of the dog family.

Predatory animal control, undertaken primarily in the interest of domestie stock, now incidentally extends similar protection to game, which only a few years ago became threatened with the aetual danger of local extinetion. On many of the domestic stock ranges of the West, notably in the national forests of eentral and southeastern Arizona, deer, antelope, and elk have become overabundant and threaten the forage supply for both stoek and game. This maladjustment is due partly to the ereation of game refuges that are far too large, and partly to lack of adequate provision for the harvesting of the game crop. In such places, where hunters are unable to utilize the game, projects of predatory animal repression should be pressed only as necessary to prevent serious injury to local economic interests.

Buffalo and Other Big Game: The herds of wild and semidomesticated buflalo that range in an isolated part of Yellowstone National Park and the larger herds in Canada, together with numerous groups under fence, 
assure the perpetuation of a species once threatened with extermination. Deer, moose, and black bears now tend to increase where accorded protection, especially in some of the national parks. A few caribou still persist in continental Lnited States in an area closed to hunting in northern Minnesota.

Mountain Sheep, or Bighorns: Formerly widely dispersed in the more rugged sections of the West, mountain sheep, or bighorns, still occur in places in the higher mountains in the national forests and national parks, and in the desert ranges of the Southwest, usually in small bands. As a rule these show little or no increase, although under the laws of most States no killing is permitted. In many sections local extinetion was due to unrestricted hunting, especially for meat to supply mining camps. There seems to be good reason to believe that scabies and perhaps other discases introduced by domestic sheep have killed many mountain sheep; and predatory animals have taken their toll. In some parts of the public domain little utilized by man the causes that led to the elimination of mountain sheep appear no longer to be operative. Mlines have been worked out and abandoned. Domestic sheep are now dipped and kept more generally free from scabies, and under proper control nuay be excluded from areas especially adapted to their wild relatives. In some of the rugged, desert mountains, especially of California, Nerada, Arizona, and New Mexico, there is sufficient forage, but ranges cannot be used by domestic stock of any kind except possibly at certain seasons, owing to lack of water, which, however, could be made arailable at moderate cost by impounding the run-off at farorable sites. Many such areas, now scarcely utilized for any purpose, could undoubtedly be stocked and developed as excellent mountain sheep ranges. Owing to the habit of twinning, mountain sheep have a high potential rate of increase, a rate actually attainable under favorable conditions, as shown for a time on the National Bison Range, in Montana. A system of well-administered Federal mountain sheep refuges would encourage State conserration efforts and should in a few years afford a surplus for stocking many ranges on which limited hunting of one of the finest game animals in the world could be permitted.

Antelope: The antelope, regarded by many as the most beautiful and characteristically American of our gane nammals, have decreased rapidly in most places during recent years. Though they still occur in parts of most of the Western States, many of the smaller groups, unfortunately, are in sections where unfarorable local conditions make their extinction practically certain. Antelope hare held on with remarkable tenacity, but they are not likely to survive except on areas where they are accorded special protection. They are reasonably safe in the national forests and national parks, but much of their natural range is on the public domain or on lands to which adequate protection or management has not extended. In some sections, howerer, as in parts of Arizona, California, Nevada, Oregon, and Wyoming, protective measures have farored substantial increases. On the Coconino National Forest and adjoining territory in Arizona, where extinction secmed imminent a few years ago, antelope have now increased to thousands. In the competition between antelope and domestic stock, the low-growing food plants are cropped with killing effect, and the nomal forage supply is so diminished that the antelope are forced to browse on junipers and other unpalatable trees as high as they can reach, leaving them completely defoliated to a sharp line that is always indicative of seriously destructive orerntilization on stock or game ranges. Such forage curtailment, increasing general surface erosion, results in rapid, permanent deterioration of the range and starration on a large scale. Here the mounting numbers of the antelope, on areas closed to bunting, like those of other game in many parts of the West, have been coincident with the control of predatory animals, mainly coyotes, instituted primarily in the interest of domestic stock production.

The general public, and even many who regard themselves as conservationists, often uninformed and accustomed to think of the antelope as a ranishing species, may oppose that feature of game management that inrolves the killing of surplus animals. This case is an example, of which many could be cited, of the necessity for clearer general understanding of the requirements of game and the urgent need for its consistent management in well-considered plans for the multiple use of land.

Wyoming contains far unore surviving antelope than any other State, and, as in some other places, mounting numbers on the public domain constitute local problems pressing for solution. Federal refuges established primarily for antelope in suitable sections of the public domain in several Western States would also extend needed protection to mule deer and sage hens. On other parts of the public domain the grazing of domestic stock should be controlled in accordance with the reasonable needs of game as well as with a view to watershed protection and the prevention of soil erosion.

Deer: Owing to large numbers and wide distribution the deer are by far the most important of the big game of the Lnited States. They constitute a national resonce capable of great derelopment. Although now extinct orer large areas formerly occupied, four species of deer still divide territory or overtap in geographic 
range. In order of importance these are, first, the white-tailed, or Virginia, deer of the Eastern and Northern States, extending west and invading the general territory of the mule deer in the northern Rocky Mountain region. Second in importance is the mule deer, commonly ealled the blacktail, of the more arid West, from the Roeky Mountains west to the Cascades, reaching the Pacific coast in southern California and extending southward into Mexico. Third, the true blacktail of the Pacific coast region, the close relative of the mule deer, occurs from California north to southeastern Alaska. And, fourth, the Arizona whitetail of the mountains of southem Arizona, southern New Mexico, and western Texas, has a main range extending far south along the Sierra Madre of Mexico. As these four members of the deer family are quite distinet and also differ considerably in the eharacter of terrain occupied, their relations to one another should be clearly understood and considered in connection with plans for land utilization.

Elk: The elk, one of the largest and most majestic members of the deer family, had a range measured originally by the width of the continent, from Pennsylvania to California. Unfortunately so large an aninal can be destructive to agricultural interests, and like the buffalo, its displacement in densely settled communities was inevitable. Thousands lave remained, however, in the wilder parts of the Rocky Mountain region, ehiefly in and around Yellowstone National Park, and in the mountains nearer the Pacifie coast in Oregon and Washington. These elk are of special interest, as they constitute the only really large herds of big game remaining in the United States, exclusive of Alaska, but while comparatively mumerous they are mere remnants of the former great herds.

In the West, the elk were aeeustomed to summer largely in the ligh mountains and to migrate to wintering areas on the lower mountain slopes and the surrounding plains, where there was less snow and abundint food. Oeeupation of the grasslands at the lower levels for agricultural purposes or for grazing stock forced many of the elk to winter in the higher and more inacessille mountains, where they suffer pitifully, many dying from starvation and disease in hard winters. The result has been the elk problem about whieh so much has been written.

The preservation of the elk is a land utilization problem of major importance. Elk of a northern group are fed in winter in Yellowstone National Park by the National Park Service. Those of a more southerm group winter in the Snake River drainage, in Jackson Hole, Wyo. Here the Winter Elk refuge, embracing 4,500 acres of meadow land, maintained by the Bureau of Biological Survey, together with supplemental feed provided by the Wyoming Game Commission, has repeatedly prevented a final disaster. Several thousand elk frequently congregate on the feeding ground, where they erowd close about the wagons from which the hay is distributed, and the spectacle thus presented is one long to be remembered by the fortunate visitor to the place. But sueh large concentrations are undesirable, and the feeding facilities are inadequate. In a solution of the problem of winter range and forage for these elk, about 12,000 aeres of additional land are urgently needed. Authorization for the aequisition of this land lias now been obtained, and actual acquisition is under way. A bill providing for the acquisition of the lands seleeted lias been before Congress for several years.

Elk are hardy animals, adapted to a fairly wide range of conditions. Owing to their large size they are nore destructive to agrieultural interests than the smaller deer, and for this renson they should not be introduced in the vicinity of farming communities. In some of the wilder and more mountainous parts of the West, however, the range of the elk might be extended. Under proper nanagement, surplus elk should afford not only rare sport but an ample supply of excellent meat for the fortunate hunter. As hunting is prohibited in national parks, the provision of open hunting grounds for elk should be given careful consideration in connection with any plans for park extension.

Management of Beavers and Other Fur Animals: The original range of the beaver included practically the entire country. This fine fur bearer is at home along streams in suitable places from the lower Rio Grande and the lower Colorado River on the Mexican boundary to near timber line on the highest mountains. It is easily trapped and was eliminated or reduced to small numbers in many localities, where it should be restored and colonies increased as a major asset. Like many other kinds of wildlife, beavers require expert management. The location of their dams may in some places seriously injure other important human interests. Roads or fields may be flooded, or valuable timber killed. Fortunately beavers ean readily be trapped and moved alive and uninjured to sites where their activities will do no harm. At low elevations streams desired for trout fishing may become too sluggish and warm owing to the impounding of water by beavers, but cold, swiftly flowing streams at the higher elevations are more likely to be improred for these fish, as the dams tend to equalize the stream flow and prevent erosion. In many forested sections food is abundant and general conditions are still suitable for beavers. Under proper management the value of the annual fur erop from this source alone could be made to reach high figures.

Other fur bearers, as the muskrat, marten, mink, and raccoon, should be more adequately managed, with a view to developing neglected wildlife assets.

Forest Game Restoration: Along with the clearing of forests incident to settlement in the eastern United 
States, the game, notably the deer that played an important part in pioneer derelopment, disappeared or were greatly reduced in numbers as they were hunted and killed without stint. With the decline of the deer, the larger predatory animals that preyed upon them-mountain lions and wolves-beeame extinct nearly throughout the East.

Much of the forested land, howerer, was too mountainous or rocky for agricultural purposes. The large, mature timber was gradually cut for use in construction of many kinds. The logging operations, taking about all the merchantable timber, were extended successively from area to area nearly throughout the forested regions of the East, continuing over a long period down to the present. In the original forest, the older trees, largely hemlock, white pine, and mature hardwoods, heavily shaded the ground. The result of the shading was a thin stand of small trees, berryproducing shrubs and other regetation, and a limited supply of tender browse for deer and fruit for bears and other wildlife. The removal of the forest canopy through lumbering operations, however, brought a great change. The dense new growth springing up afforded far more food and cover for game. The larger predatory animals were eliminated as has been mentioned. In marginal or submarginal territory, such as in many sections of the Ozark Mountain section of southern Missouri and northern Arkansas, and the Appalachian Mountain region in half a dozen States, now virtually barren of game, the forest setting has thus been prepared for the restoration of deer, bears, rabbits, grouse, and wild turkeys on a scale far exceeding the game populations of the same areas before the coming of the white man. If such areas were restocked and properly administered, the annual game and fish crop that could be taken would go far to relieve the general poverty so prevalent there at the present time. The phenomenal success of forest-game restoration in cut-over areas in Pennsylrania, New York, Michigan, and other States where large predatory animals are now absent or scarce is indicative of what could be done in similar sections in many other States.

Conditions in the West differ materially from those in the East, as the western forests have been cut over only in part, domestic stock grazing is a more important factor to be reckoned with, and large predatory animals, especially coyotes, are still numerous. The remarkable increases in game, especially deer and antelope, coincident with predatory animal control undertaken priinarily to protect domestic animals, have already been mentioned. In spite of these differences it is evident that the general principles bearing upon the relation of game to the use of forested lands in the West are the same as in the East.

IVildlife Refuge Needs: The importance of establishing more refuges, Federal, State, municipal, and private, as a part of a comprehensive program of wildlife man- agement, is becoming more generally recognized; but these must he suitably located and properly arlministered to achieve their highest usefulness.

Wildlife refuges of one kind or another are under the jurisdiction of several departments of the Federal Gorernment, their varied situations heing largely due to expedieney, as the control of wildlife tends to run concurrently with that of the land (or water) it inhabits. The national parlis under the Interior Department and refuges on the national forests under the Forest Service, Department of Agriculture, have alrealy been mentioned. Over 100 refuges, mainly for birds, but inclucling a few big game ranges, under the Burean of Binlogical Surver, Department of 1 griculture, are far flung in general distribution-from Puerto Rico and the constal islands of the United States, to the Aleutian Archipelago in Alaska and islands of the Hawaiian group. These Federal refuges are administered with special emplasis on the interests of all the wildlife found on them. The protection of marine mammals, notably the northern fur seal, which breeds on the Pribilof Islands, and the sea otter, is intrusted to the Bureau of Fisheries, Department of Commerce.

Specialized Refuge Needs for Upland Game: The ideal upland game refuge is a protected area that will favor the rapid increase of game within its borders and from which the surplus may readily spread to suitable surrounding territory that may be open to hunting. It need not necessarily be very large, but alone or in conljunction with neighboring refuge units should provide year-long range, ample forage, water, and cover for resident game. This is the type of refuge that bas succeeded so admirably in building up the game supply in the State forests of Pennsylvania and other Eastern States, and on Federal and State refuges on the national forests, mainly in the West. Wherever game thrives, a surplus representing a game crop may reasonably be expected. It can be removed by hunters, consumed by predatory animals, or allowed to die of starvation or disease. Game management, therefore, calls not only for adequate protection but the prompt and wellplanned disposal of all surplus. The national parks serve as great game reservations in which no shooting by sportsmen is allowed.

Game Refuge Needs on Forests: Additional refuges of suitable size and distribution should be created for forest game in the forested areas, but are even more urgently needed for restoring mountain sheep, antelope, mule deer, peecaries, sage hens, and other denizens of the more arid parts of the public domain. The unwieldy surplus of deer, antelope, and elk that has already resulted from orerprotection in certain places should not be taken to mean that the protective principle is wrong, or that additional refuges are not desirable, but should be considered as examples of game mismanagement. 
W'aterfowl Refuge Area Needs: While a sufficient breeding stock of most kinds of upland game, and even of some of the more important fur bearers, seems within relatively easy reach, the plight of our migratory waterfowl is far more critical. Human encroachment, the primary cause of the great reduction of waterfowlducks, geese, and swans-that formerly nested in the Prairie States of the Middle West, and the Prairie Provinces of Canada, and migrated sonthward in uncounted millions, has already been described. To this primary cause should be added orershooting by an ever-increasing army of hunters. The combined unfavorable influences hare led to the diminution of waterfowl at a rapidly accelerating rate, and, unless they can be modified, they must lead to the early extermination of one species after another. In order to check the depletion of breeding stocks of waterfowl common to the United States and Canada, especially the ducks and geese, Federal regulations are annually promulgated under the Migratory Bird Treaty with Great Britain. State laws and regulations tend to conform with those of the Federal Government; but restrictive regulations alone will not suffice to save the birds. An appraisal of the relative value of many prairie areas before and after drainage brings into relief the vital importance of putting into effect a wildife restoration program by the Federal and State Governments in cooperation with all other agencies interested. A system of Federal refuge areas, covering especially the Niddle West and the great migration flyway through the Mississippi Valley, is planned to take the form of inviolate refuges, on which the birds can breed unmolested, and on which also they will have feeding and resting grounds.

Wildlife Management on Privately Owned Lands: Meanwhile the cooperation of private landowners should be enlisted, with a view to restricting as far as practicable the grazing of domestic stock and other destructive practices about prairie ponds and in marsh areas of critical importance to breeding waterfowl.

On Farms: The relation of small game, as rabbits and squirrels, the fur bearers, and the various species of upland game birds, to private holdings, and especially farmland utilization, is of major importance owing to the vast extent of the land involved. The cultivation of land brings radical changes in environmental conditions, and these may be either beneficial or harmful, depending on the varying needs of the different classes of wildlife. Farm operations may provide an abundance of food and shelter at certain seasons and leave the game and fur bearers bereft of these prime necessities at others.

The attitude of the farmer toward the hunter has an important bearing in this connection. Farm game, the fur bearers, and the fishes should be regarded as having a potential crop value similar to that of any other product of the soil. Since a farm must be managed for profit, there should be recognition of the fact that the farmer has a proprietary interest in the game attached to his land, and that he is justly entitled to a monetary return, proportionate to his efforts in its behalf. He should be encouraged to expect a profit through the sale of shooting or trapping rights, under regulations fixed by the State. The relation of local game, fur bearers, or fishes to other farm crops of the region should be clearly understood. Rabbits, for example, may be too numerous and injurious to field crops or to horticulture in a given locality, while a larger number would be harmless or even lighly desirable in another place. The food and cover required for wildlife may be provided by less intensive cultivation of land, in conformity with current human needs. In the Prairie States many hedgerows and bordering thickets, with a highly beneficial windbreak value, and incidentally affording game food and shelter, were uprooted and displaced by barbed wire in order to make the land yield a little more grain in war time. The result has been increased wind erosion, soil exbaustion, and game elimination. Obviously, and in conformity with the shelter belt idea, such hedgerows should be restored for their beneficial effect in the general use of the land. The strip cultivation of land, employed to prevent wind erosion and as a crop reduction measure, could also be made the means of increasing farm game.

On Areas Generally: Wildlife, in its multiplicity of forms adapted to every sort of environment, should be accorded its proper place in the use of land everywhere. It should be recognized as a rich endowment, one to be wisely managed and used, and then passed on unimpaired to future generations.

\section{Public Areas Employed As Specialized Refuges}

Administered by the Bureau of Biological Survey: Federal areas devoted exclusively to wildlife protection under the administration of the Bureau of Biological Survey, United States Department of Agriculture, include more than 900,000 acres of surveyed lands in the United States, besides unsurveyed islands in Alaskia, Hawaii, and Puerto Rico. A list is given in table I and acreagres by States in table II. Most of these refuges are specifically for the protection of birds, but several big-game preserves, on which birds also are protected, are included.

Administered by the Bureau of Fisheries: The Pribilof Islands, Alaska, of 49,000 acres, are administered by the Bureau of Fisheries, Department of Commerce, primarily for the conservation and utilization of the fur seals. 
TABLE I,-Specialized wildlife refuges under administration by the Bureau of Biological Survey, shoving the year established, the acreage of the surveyed lands, and the chief species for the protection of which each w'as established

\begin{tabular}{|c|c|c|c|}
\hline State and designation & $\begin{array}{l}\text { lear } \\
\text { estat- } \\
\text { lished }\end{array}$ & Acres & Chief species proteeted \\
\hline $\begin{array}{l}\text { Alabams } \\
\text { Petit I }\end{array}$ & 1903 & 956 & $\begin{array}{l}\text { Laughing gulls, least terns, black } \\
\text { skimmers, Louristana herons, brown }\end{array}$ \\
\hline $\begin{array}{l}\text { Alaska: } \\
\text { Alaska Railway MIusk. } \\
\text { rat and Beaver Ret- }\end{array}$ & 1927 & t, 160 & $\begin{array}{l}\text { pelicans. } \\
\text { Muskrats, bearers. }\end{array}$ \\
\hline $\begin{array}{l}\text { Mge. } \\
\text { Alentian Islands. . . . . }\end{array}$ & 1913 & (I) & $\begin{array}{l}\text { Puffius, aublets, murres, gulls, dueks, } \\
\text { geese, ptarmlgan, sea atters, red and } \\
\text { blue toxes; ou Unimak Island cari- } \\
\text { bnu, big-brow bears. }\end{array}$ \\
\hline 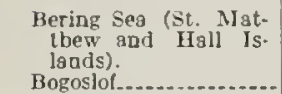 & 1909 & (1) & $\begin{array}{l}\text { Puffins, auklets, kittiwakes, glaucous } \\
\text { gulls, sandpipers, snow buntings. }\end{array}$ \\
\hline Chamisso Island... & 1912 & $\begin{array}{l}\text { (') } \\
\text { (1) }\end{array}$ & $\begin{array}{l}\text { Puffins, auklets. murres, gulls, sea } \\
\text { lions, } \\
\text { Iorned puffins, Palles murres, Pacific }\end{array}$ \\
\hline $\begin{array}{l}\text { Curry Bird, Game, } \\
\text { and Fish Refuge. } \\
\text { Forrester Island....... }\end{array}$ & $\begin{array}{l}1927 \\
1912\end{array}$ & 8.960 & $\begin{array}{l}\text { kittiwakes, glawcous gulls. } \\
\text { Grouse, ptarmigan, black bears, fores, } \\
\text { lynx, ermines, fishers. } \\
\text { Puffins, auklets, guillemots, murres, }\end{array}$ \\
\hline Пazy Island... & 1912 & (1) & $\begin{array}{l}\text { gulls, petrels, cormorants. } \\
\text { Puffins, auklets, guillemots, murres, }\end{array}$ \\
\hline Nunirak Island.. & 1929 & (1) & $\begin{array}{l}\text { gulls, cormorants. } \\
\text { Water [ow], ptarmigac, reindeer, cari- }\end{array}$ \\
\hline St. Lazaria... & 1909 & (1) & Puffins, auklets, guillemots, murres, \\
\hline $\begin{array}{l}\text { Semidi Islands........... } \\
\text { Tuxedni .................... }\end{array}$ & $\begin{array}{l}1932 \\
1909\end{array}$ & $\begin{array}{l}8,290 \\
(1)\end{array}$ & $\begin{array}{l}\text { Puffins, avklets, petrels. } \\
\text { Paeific kittiwakes, glaucous gulls, }\end{array}$ \\
\hline $\begin{array}{l}\text { Arkansa } \\
\text { Big L }\end{array}$ & 1915 & 8, 937 & $\begin{array}{l}\text { eider ducks. } \\
\text { Ducks. }\end{array}$ \\
\hline $\begin{array}{l}\text { Calíornia: } \\
\text { Farallo }\end{array}$ & 1908 & 91 & Puffins, auklets, guillemots, murres, \\
\hline $\begin{array}{l}\text { Delaware: } \\
\text { Killcohook (see also } \\
\text { New Jersey). }\end{array}$ & 1934 & 586 & Ducks, geese, muskrats. \\
\hline & 1925 & 12 & Browa pe \\
\hline & & 10 & \\
\hline & $\begin{array}{l}1929 \\
1932\end{array}$ & 2,033 & $\begin{array}{l}\text { DS. } \\
\text { pland game }\end{array}$ \\
\hline Indian Key... & 1906 & 90 & $\begin{array}{l}\text { Brown pelicans, white ibises, egrets, } \\
\text { Louisiana and little blue berons. }\end{array}$ \\
\hline $\begin{array}{l}\text { Island } \\
\text { Key } 1\end{array}$ & $\begin{array}{l}1908 \\
1908\end{array}$ & $\begin{array}{l}3,321 \\
2,030\end{array}$ & \\
\hline & & $\begin{array}{r}267 \\
10 \\
1\end{array}$ & $\begin{array}{l}\text { Black sk } \\
\text { Cormora } \\
\text { Herons. }\end{array}$ \\
\hline Passag & 1905 & 36 & ers, eor- \\
\hline & $\begin{array}{l}1903 \\
1903\end{array}$ & $\begin{array}{r}15 \\
31\end{array}$ & \\
\hline Georg & 1931 & 36,862 & $\begin{array}{l}\text { Gulls, dueks, geese, sandpipers and } \\
\text { other shore birds. }\end{array}$ \\
\hline & 1926 & 4. 6539 & $\begin{array}{l}\text { Herons, ducks, elapper rails, quail, } \\
\text { chaehalacas, white-tailed deer, rac- } \\
\text { conns, onossums. }\end{array}$ \\
\hline $\begin{array}{l}\text { Savanaab R } \\
\text { also Sout } \\
\text { lina). }\end{array}$ & 1927 & 424 & Ducks, herons, rails, coots, sbore birds. \\
\hline & 1930 & 538 & W'aterlowl, shore birds. \\
\hline IIawaiian Islands...... & 1909 & (1) & $\begin{array}{l}\text { Terns, albatrosses, petrels, shearwaters, } \\
\text { boobies, man-o'-war birds, Laysan } \\
\text { leal, rails, fnches. }\end{array}$ \\
\hline Johnston Isl & 1926 & (1) & $\begin{array}{l}\text { Sonly and noddy terns, wedge-tailed } \\
\text { shearwaters, petrels, boobies, man- } \\
0^{\prime} \text {-war birds. }\end{array}$ \\
\hline $\begin{array}{l}\text { Upper Mississippl } \\
\text { River Wildlife and } \\
\text { Fish Retuge (see also } \\
\text { Iowas Minnesota, } \\
\text { and Wisconsin). }\end{array}$ & 1925 & 19,759 & $\begin{array}{l}\text { Ducks, geese, shore birds, upland game } \\
\text { birds, muskrats, minks, beavers, } \\
\text { foses, raccoous, tishes, mollusks. }\end{array}$ \\
\hline $\begin{array}{l}\text { OWa: } \\
\text { Upper Mis } \\
\text { River Wil } \\
\text { Fisb Refuge } \\
\text { Illinois, MI } \\
\text { 3nd Wiscor }\end{array}$ & 1925 & 30,616 & Do. \\
\hline & 1904 & 955 & $\begin{array}{l}\text { Laughiug gulls, royal sud Cabot's } \\
\text { terns, skimners, herons, willets. }\end{array}$ \\
\hline East TImbalier... & 1907 & 337 & \\
\hline & $\begin{array}{l}1907 \\
1904\end{array}$ & 1,000 & s and \\
\hline & 1933 & 12 & Ducks, geese. \\
\hline & 1932 & 8,211 & $\begin{array}{l}\text { Dueks, sandpipers and other shoro } \\
\text { birds, muskrats. }\end{array}$ \\
\hline $\begin{array}{l}\text { Michlgat } \\
\text { Hurou } \\
\text { Siskiw }\end{array}$ & $\begin{array}{l}1905 \\
1005\end{array}$ & $\begin{aligned} 83 \\
9\end{aligned}$ & $\begin{array}{l}\text { Herrlng gulls, ducks. } \\
\text { Do. }\end{array}$ \\
\hline
\end{tabular}

TABLE I.-Specialized wildlife refuges under administration bu the Bureau of Biological Survey, showing the year established, the acreage of the sumryed lands, and the chicf species for the protection of which each was establishert-Continued

\begin{tabular}{|c|c|c|c|}
\hline State anul desiguation & $\begin{array}{l}\text { Year } \\
\text { estab- } \\
\text { lished }\end{array}$ & Acres & Chief species protected \\
\hline $\begin{array}{l}\text { Minnesola: } \\
\text { Mille Lacs }\end{array}$ & & & \\
\hline $\begin{array}{l}\text { Mpper Mississippi } \\
\text { River Wildlite and } \\
\text { Fish Refuge (sce also } \\
\text { Iowa, Illiuois, and } \\
\text { Wisconsin). }\end{array}$ & $\begin{array}{l}1915 \\
1925\end{array}$ & $23,25 \times$ & $\begin{array}{l}\text { Gulls, ducks, geese. } \\
\text { Ducks, geese, shore birds, upland garne } \\
\text { birds, muskrats, muinks, beavers, } \\
\text { toxes, raccoons, fishes, mollusks. }\end{array}$ \\
\hline $\begin{array}{l}\text { Montana: } \\
\text { Benton Lake }\end{array}$ & & 12,235 & Ducks, geese, shore birds. \\
\hline $\begin{array}{l}\text { National Bisou Range. } \\
\text { Nebreska: }\end{array}$ & 1909 & 18,521 & $\begin{array}{l}\text { Ducks, grouse, pheasaats, buffalo, deer, } \\
\text { mountain sheep, elk. }\end{array}$ \\
\hline Cresce & 1931 & 40,792 & $\begin{array}{l}\text { Teras, ducks, geese, eoots, sandpipers } \\
\text { and other shore hirds. }\end{array}$ \\
\hline $\begin{array}{l}\text { Niobrara .............. } \\
\text { Nevada: }\end{array}$ & 1912 & 16,681 & $\begin{array}{l}\text { Prairie cbickens, sharp-tailed grouse } \\
\text { quail, buffalo, elk, anteloye, beavers }\end{array}$ \\
\hline $\begin{array}{l}\text { Nevada: } \\
\text { Anaho Island.... }\end{array}$ & 1913 & 245 & Gulls, cormorants, white pelicans. \\
\hline Charles & 1931 & 30,321 & Sage grouse, antelope. \\
\hline Railrond Valley..... & 1931 & 135,181 & Ducks, geese, ibises, avocets, shor: \\
\hline $\begin{array}{l}\text { Yew Jersey: } \\
\text { Killoobook (see also } \\
\text { Delaware). }\end{array}$ & 1934 & 856 & $\begin{array}{l}\text { birds. } \\
\text { Ducks, geese, muskrats. }\end{array}$ \\
\hline $\begin{array}{l}\text { Torth Carolina: } \\
\text { Lake Mrattamuskeet... }\end{array}$ & 1934 & 49,925 & $\begin{array}{l}\text { Ducks, geese, swans, shore birds, } \\
\text { muskrats. }\end{array}$ \\
\hline Swanquarter... & 1932 & 15,493 & $\begin{array}{l}\text { Ducks, geese, brant, swans, sandpipers } \\
\text { and other shore birds. }\end{array}$ \\
\hline $\begin{array}{l}\text { North Dakota: } \\
\text { Chase Lake... }\end{array}$ & 1905 & 2,960 & $\begin{array}{l}\text { Gulls, white pelicans, ducks, shore } \\
\text { birds, grouse. }\end{array}$ \\
\hline Long Lake. . . . . . . . . . & 1931 & 8.795 & $\begin{array}{l}\text { Gulls, terns, ducks, coots, and willets, } \\
\text { sandpipers and other shore birus. }\end{array}$ \\
\hline Stump Lake.... & 1905 & 27 & $\begin{array}{l}\text { Grebes, gulls, terns, dueks, Wilson's } \\
\text { phalaropes. }\end{array}$ \\
\hline Sullys Ifill.... & 1914 & 994 & $\begin{array}{l}\text { Goldeneye and wood duchs, reese, } \\
\text { pheasants, buffalo, elk, white-quiled } \\
\text { deer. }\end{array}$ \\
\hline minating & 1930 & 19,453 & $\begin{array}{l}\text { Franklin's gulls, black teros, waterfow-1. } \\
\text { bitterns, rails, shore birds. }\end{array}$ \\
\hline $\begin{array}{l}\text { Wichita Mountains } \\
\text { Wildlife Refuge.2 } \\
\text { Oregon: }\end{array}$ & 1905 & 61,500 & $\begin{array}{l}\text { Ducks, geese, wild turkeys, buiralo. } \\
\text { elk, deer, antelope, Texas lomghurns. }\end{array}$ \\
\hline $\begin{array}{l}\text { Goat Island } \\
\text { Lake Malheur.............. }\end{array}$ & $\begin{array}{l}1935 \\
1908\end{array}$ & $95,1^{21}$ & $\begin{array}{l}\text { California murres, gulls, puinos, geese. } \\
\text { Grebes, gulls, lerns, cormorants, peli- } \\
\text { cans, ducks, geese, smans, herons }\end{array}$ \\
\hline $\begin{array}{l}\text { Malheur (Blitzen Val- } \\
\text { ley). }\end{array}$ & 1935 & 61,717 & $\begin{array}{l}\text { Grebes, guls, terns, cormorants, peli- } \\
\text { cans, ducks, geese, swans, ibises, } \\
\text { herons, sandhith cranes, sage grouse, } \\
\text { deer, antelope, besvers. }\end{array}$ \\
\hline $\begin{array}{l}\text { Three Arch Roeks. .... } \\
\text { Puerto Rico: }\end{array}$ & 1907 & 17 & $\begin{array}{l}\text { Puffins, guillemots, murres, gulls, tork- } \\
\text { tsiled petrels, cormorants. }\end{array}$ \\
\hline 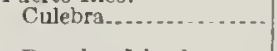 & 1909 & (1) & $\begin{array}{l}\text { Gulls, royal terns, Bahams ducks, } \\
\text { herons, eoots, ground doves, }\end{array}$ \\
\hline Desecheo Island......... & 1912 & (1) & $\begin{array}{l}\text { Terns, boobies, man-o'war hirds, } \\
\text { oyster catchers. }\end{array}$ \\
\hline $\begin{array}{l}\text { South Carolina: } \\
\text { Cape Romain }\end{array}$ & 1931 & $5 ., 061$ & $\begin{array}{l}\text { Ducks, curlews, egrets, herons, nelicans } \\
\text { ibises, sanderlings, dowitchers, oyster } \\
\text { catchers, sandpipers and other shore } \\
\text { birds, sea turtles, diannod back } \\
\text { terrapin. }\end{array}$ \\
\hline $\begin{array}{l}\text { Savanuah River (see } \\
\text { also Georgia). } \\
\text { Utah: }\end{array}$ & 1927 & 2,559 & Dueks, berons, rails, coots, shore birds. \\
\hline Bear River.............. & 1925 & 64,216 & $\begin{array}{l}\text { Ducks, geese, coots, sbore birds, peli- } \\
\text { cans, ibises, pheasants, bearers, } \\
\text { muskrats. }\end{array}$ \\
\hline $\begin{array}{l}\text { Locomotive Spriugs.... } \\
\text { Washington: }\end{array}$ & 1931 & 1,031 & $\begin{array}{l}\text { Ducks, coots, eurlews, arncets, saud- } \\
\text { pipers and other shore birds. }\end{array}$ \\
\hline Wash & 1926 & s & Gulls, ducks, geese, blue herons. \\
\hline 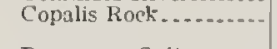 & 1907 & 5 & $\begin{array}{l}\text { Puffins, murres, glaucous and western } \\
\text { gulls, petrels, cornorants. }\end{array}$ \\
\hline $\begin{array}{l}\text { Dungeness Spit........ } \\
\text { Ediz Hook............ }\end{array}$ & $\begin{array}{l}1915 \\
1915\end{array}$ & $\begin{array}{r}227 \\
\$ 3\end{array}$ & $\begin{array}{l}\text { Grebes, loons, gults, ducks. } \\
\text { Pigeon guillemots, California murres, } \\
\text { cormorants. }\end{array}$ \\
\hline Flattery Rocks.... & $190 \%$ & 125 & $\begin{array}{l}\text { Tufted putfias, pigeon guillemots, } \\
\text { California murres. }\end{array}$ \\
\hline Smith Island... & 1911 & 65 & $\begin{array}{l}\text { Western grebes, pikeon guillenots, } \\
\text { California murres, cormorants, ducks. }\end{array}$ \\
\hline $\begin{array}{l}\text { Quillayute Necdles...... } \\
\text { Visconsin: }\end{array}$ & 190 & 117 & Grebes, auklets, guils, cornorants. \\
\hline $\begin{array}{l}\text { Gravel Islabd........... } \\
\text { Greea Bay.............. }\end{array}$ & $\begin{array}{l}1913 \\
1912\end{array}$ & $\begin{array}{r}27 \\
2\end{array}$ & $\begin{array}{l}\text { Merring gulls. } \\
\text { Do. }\end{array}$ \\
\hline $\begin{array}{l}\text { - piper Mississippi } \\
\text { River Wildite abd } \\
\text { Fish Refuge (see } \\
\text { also Iows, Illinois, } \\
\text { and Minnesota). } \\
\text { yoming: }\end{array}$ & 1925 & 64,749 & $\begin{array}{l}\text { Ducks, geese, shore birds, uplad gane } \\
\text { birds, muskrats, minks, racenons, } \\
\text { beavers, loves, fishes, moliusks. }\end{array}$ \\
\hline I3amlorth Lake........ & 1932 & 2,163 & $\begin{array}{l}\text { Ducks, geese, sandpiners and other } \\
\text { shore birds. }\end{array}$ \\
\hline Elk Reluge....... & 1912 & $4,5.5 \mathrm{~s}$ & $\begin{array}{l}\text { Ducks, geese, sage crouse, elk (in } \\
\text { wioter). }\end{array}$ \\
\hline $\begin{array}{l}\text { Flat Creek } \\
\text { II }\end{array}$ & $\begin{array}{l}1922 \\
1932\end{array}$ & $\begin{array}{r}40 \\
1,705\end{array}$ & $\begin{array}{l}\text { Ducks, geese, elk (ja wiater). } \\
\text { Dueks, geese, and snalpipers and } \\
\text { other shore birds. }\end{array}$ \\
\hline
\end{tabular}

Unsurvoyed aress. 'Jurisdiction transferred from Foreat Service, 1935. 
TABLE II.-Aercage by Stotes of surveyed lands administered as wildlife refuges by the Bureau of Biological surrey, Department of - tgriculture

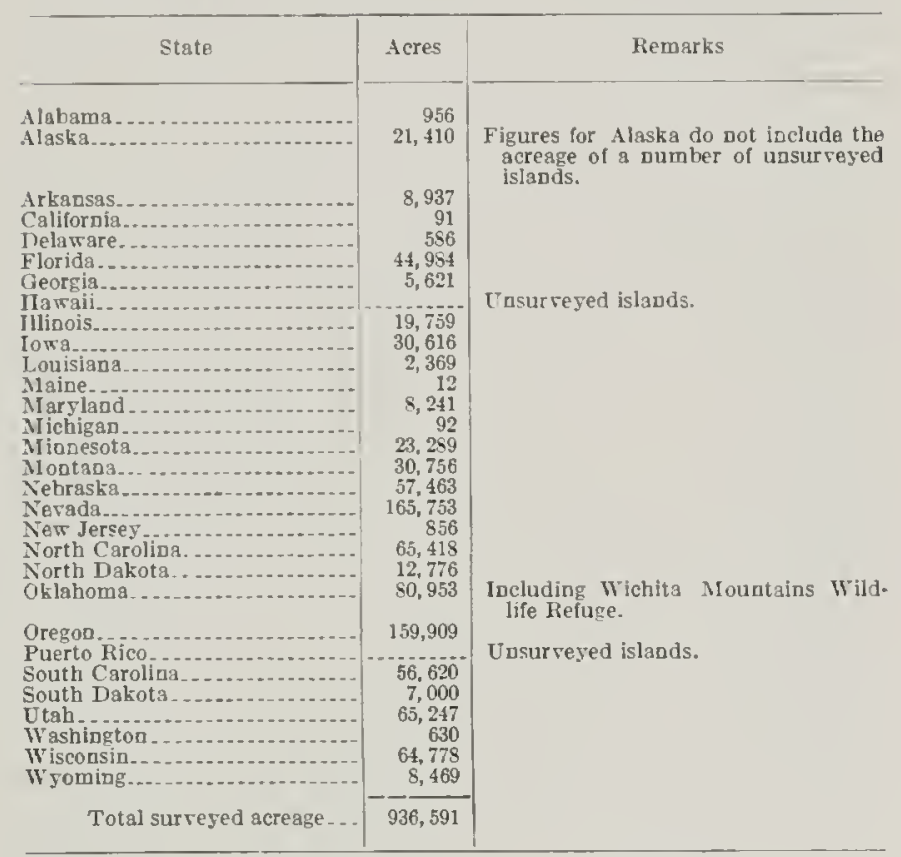

\section{Public Areas Designated \\ as Refuges but Devoted to Other Major Uses}

Administered by the Biological Surcey on Reclamation Reservoirs: In 11 States the Biological Survey administers wildlife refuges, mainly for birds, on areas the primary use of most of which is as reservoirs under projects dereloped by the Burenu of Reclamation of the Interior Department (tables III and IV). As there is usually wide fluctuation of water levels, however, their value for wildlife is limited.

Administered by Other Federal Agencies: Publiely owned areas administered by several Federal ageneies have been devoted primarily to rarious najor uses and designated as wildlife refuges, as shown in table $\mathrm{V}$.

State Game Refuges: The list in table VI will indicate the approximate acreage nominally in State game refuges. Some areas are State owned or leased, and

TABle III.-Acreage by States of Reclamation Service reservoir areas administercd as bird refuges by the Biological Survey

\begin{tabular}{|c|c|c|}
\hline State & Acres & Remarks \\
\hline $\begin{array}{l}\text { Arizona } \\
\text { California } \\
\text { Idaho } \\
\text { Montana } \\
\text { Nebraska } \\
\text { Nevada } \\
\text { Now Merico } \\
\text { Oregon } \\
\text { South Dakota. } \\
\text { Utah } \\
\text { Washington } \\
\text { Wyoming }\end{array}$ & $\begin{array}{r}333,807 \\
88,763 \\
25,540 \\
67,870 \\
5,107 \\
360,513 \\
91,908 \\
94,249 \\
13,680 \\
14,080 \\
1,120 \\
34,949 \\
\end{array}$ & Including Boulder Canyon project. \\
\hline Total acreage............. & $1,131,586$ & \\
\hline
\end{tabular}

others are Federal lands, chiefly in national forests, on which the States exercise jurisdiction over the game. Owing to frequent ehanges in status the figures are incomplete and subject to constant eorrection.

\section{Public Areas Needed for Specialized Refuges}

Additional Federal lands needed for the purpose of specialized wildlife refuges fall into two main divisions, as follows:

For Cpland Game: Parts of the unreserved public domain, aggregating $21,000,000$ acres needed for upland game, especially such big game mammals as mountain sheep, antelope, and mule deer.

For Migratory Birds: Marsh and water areas, aggregating $17,000,000$ acres, needed for the restoration and conserration of waterfowl, mainly ducks, geese, and swans, in accordance with a national plan, in furtherance of the Migratory Bird Treaty protecting birds that pass the year between Canada and the United States.

TABLE IV.-I'ildlife refuges administered by the Bureau of Biological Survey on areas primarily devoted to other uses-chiefly on reservoirs for irrigation projects of the Bureau of Reclamation

\begin{tabular}{|c|c|c|c|}
\hline State and designation & $\begin{array}{l}\text { Year } \\
\text { estab- } \\
\text { lished }\end{array}$ & Acres & Chief species protected \\
\hline $\begin{array}{l}\text { Arizoda: } \\
\text { Boulder Car } \\
\text { also Nerac } \\
\text { Salt River.- }\end{array}$ & & 312,0 & Waaterfotrl, mammals. \\
\hline $\begin{array}{l}\text { California: } \\
\quad \text { Clear Lake }\end{array}$ & 1911 & 21,120 & $\begin{array}{l}\text { Cormorants, white pelicans, ducks, } \\
\text { geese. } \\
\text { Gulls, cormorants, white pelicans, }\end{array}$ \\
\hline $\begin{array}{l}\text { Lake (see } \\
\text { regon) }\end{array}$ & $\begin{array}{l}1908 \\
1930\end{array}$ & 45,560 & $\begin{array}{l}\text { Gulls, cormorants, white pelicans, } \\
\text { geese, herons, ducks. } \\
\text { Gulls, ducks, geese, coots, shore birds. } \\
\text { Pellians, ducks, geese, coots, shore } \\
\text { hirds. }\end{array}$ \\
\hline $\begin{array}{l}\text { Tule I } \\
\text { Idaho: }\end{array}$ & 1928 & 9,363 & Ducks, geese, shore hirđ̄s. \\
\hline $\begin{array}{l}\text { Deer Flat } \\
\text { Minidoka }\end{array}$ & $\begin{array}{l}1909 \\
1909\end{array}$ & $\begin{array}{l}12,300 \\
13,240\end{array}$ & $\begin{array}{l}\text { Ducks, geese, pheasants. } \\
\text { Grebes, Forster's terns, cormorants, } \\
\text { white pelicans, ducks, coots, herons, } \\
\text { avocets, sagg grouse. }\end{array}$ \\
\hline Jing & 1929 & 56,954 & $\begin{array}{l}\text { Grebes, hlack terns, ducks, geese, coots, } \\
\text { bitterns, phalaropes, arocets, sand- } \\
\text { pipers, yellorrlegs, plovers, sharp- } \\
\text { tailed grouse, pheasants. }\end{array}$ \\
\hline & $\begin{array}{l}1921 \\
1921\end{array}$ & $\begin{array}{l}2,022 \\
2,540\end{array}$ & $\begin{array}{l}\text { Ducks, coots. } \\
\text { Do. }\end{array}$ \\
\hline & & & Gulls, ducks, geese, swans. \\
\hline Nebra & & & \\
\hline Nevad & 1916 & 5,107 & Ducks, geese, stads, shore birds. \\
\hline $\begin{array}{l}\text { Boulder Canyon (see } \\
\text { also Arizona) } \\
\text { Fallon...................... }\end{array}$ & $\begin{array}{l}1933 \\
1931\end{array}$ & $\begin{array}{r}346,443 \\
14,0 ; 0\end{array}$ & $\begin{array}{l}\text { Waterforl, mammals. } \\
\text { Gulls, terns, ducks, pelicans, cormo } \\
\text { rants. }\end{array}$ \\
\hline $\begin{array}{l}\text { New Mlexico: } \\
\text { Carlsbad } \\
\quad \text { Rio Graude.................... }\end{array}$ & $\begin{array}{l}1909 \\
1909\end{array}$ & $\begin{array}{l}18,680 \\
73,228\end{array}$ & $\begin{array}{l}\text { Ducks, shore birds. } \\
\text { Orebes, cormorants, ducks, g }\end{array}$ \\
\hline $\begin{array}{l}\text { Oregon: } \\
\text { Cold }\end{array}$ & 1909 & 2,677 & $\begin{array}{l}\text { Ducks, geese, swans, herons, sharp- } \\
\text { tailed grouse. }\end{array}$ \\
\hline $\begin{array}{l}\text { Klamath Lake (see } \\
\text { also California). }\end{array}$ & 1908 & 81,619 & Gulls, ducks, geese, coots, shore birds \\
\hline & $\begin{array}{l}1927 \\
1925\end{array}$ & $\begin{array}{l}1,813 \\
8,140\end{array}$ & $\begin{array}{l}\text { Ducks, geese. } \\
\text { Do. }\end{array}$ \\
\hline $\begin{array}{l}\text { South } \mathrm{Da} \\
\text { Belle }\end{array}$ & 1909 & 13,650 & $\begin{array}{l}\text { Ducks, geese, curlews, prairie chickens, } \\
\text { pheasants. }\end{array}$ \\
\hline $\begin{array}{l}\text { Utah: } \\
\text { Strawt } \\
\text { Washingto } \\
\text { Concor }\end{array}$ & 1909 & 14,080 & Ducks, sage grouse. \\
\hline & 1909 & 1,120 & $\begin{array}{l}\text { Gulls, ducks, herons, sooty and sharp } \\
\text { tailed grouse, Hungarian partridges }\end{array}$ \\
\hline $\mathrm{Pa}$ & 1928 & 34,949 & Ducks, geese. \\
\hline
\end{tabular}


TABLE V.-Areas administered as wildlife refuges by other departments incidental to their primary use

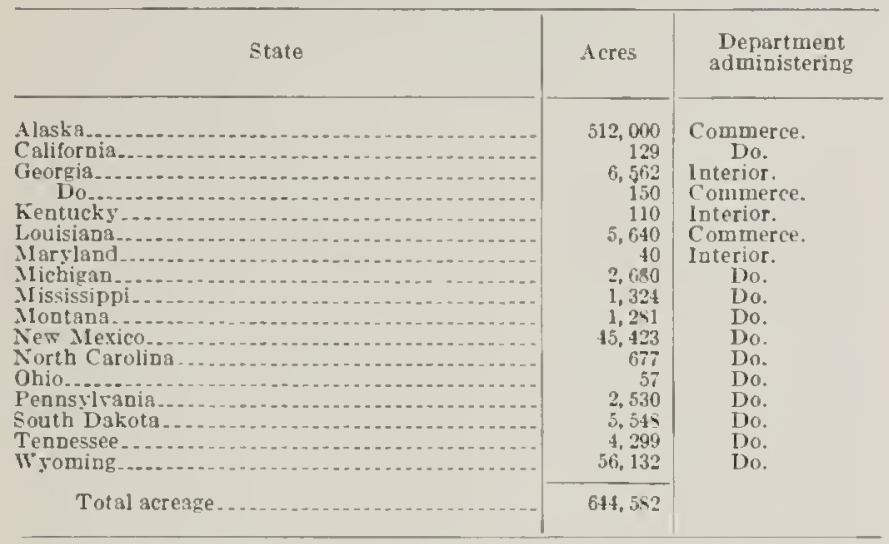

Public Areas In Other Uses

That Should Be Designated

\section{as Wildlife Refuges}

For a discussion of this subject see contributions by the Forest Service and the National Park Service.

\section{Private Lands Employed as a Habitat for Wildlife}

Nenrly all privately owned lands bearing regetation are, or may be, employed as a habitat for some form of wildlife. In many States no shooting is allowed on certuin areas, and these, therefore, function as wildlife
TABLE VI.-Areas nominally in State game refuges, 1981

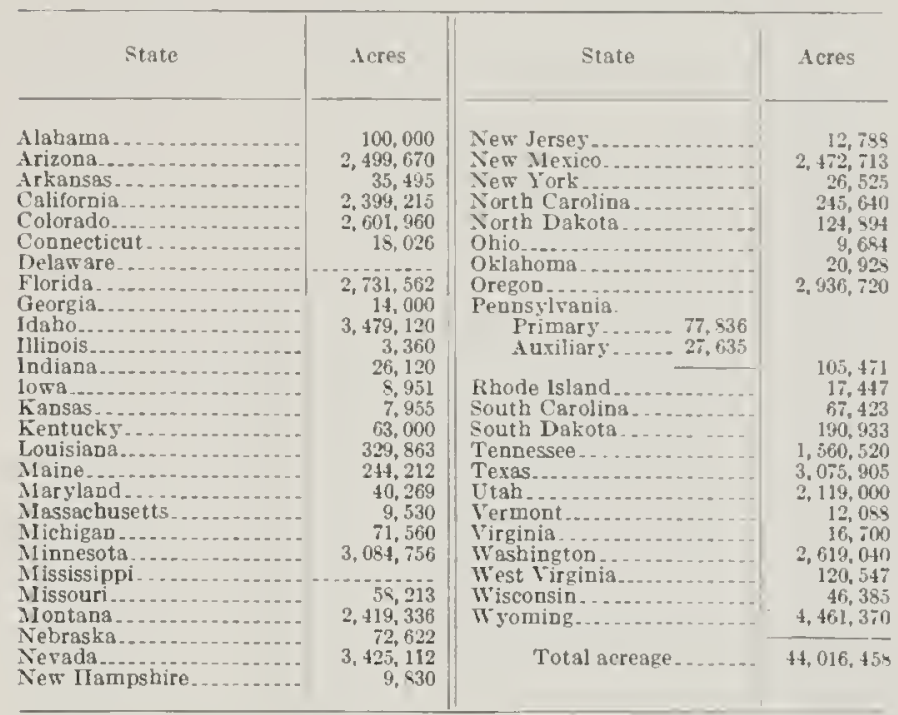

refuges. Marsh areas, fence rows, and tree- or shrubbordered stream or ditch banks should be utilized for wildlife production. Recommendations by the Biological Survey for improving the farm environment for wildlife have been set forth in a recent publication of the Departmient of Agriculture. ${ }^{5}$

3 Orange, W. B., and McAtee, W. L. IMPRovisg the FARM Exironient for Wridufe. U. S. Dept. Agt. Farmers' Bul. 1719, 62 pp., illus. 1934. 


\section{Areas Now in Public Ownership Devoted to Wildlife}

Federal Ownership: Among Federal lands on which wildlife is protected are national parks, national forests, certain national monuments, and national wildlife refuges established specifieally for game birds and mammals, fur bearers, and other valuable and interesting forms of animal life. For all these there should be formulated definite policies with respect to wildlife.

Specialized: There are now under Federal ownership and administered by the Bureau of Biological Survey, of the Department of Agriculture, approximately 1,000,000 acres of surveyed lands in the United States, specifically deroted to wildlife protection, besides unsurveyed islands of some extent designated for the purpose in Alaska, Hawaii, and Puerto Rico. Iost of these areas are breeding and feeding grounds for birds, including some for sea birds and migratory waterfowl, but a few big game and fur animal refuges also are included. Table II gives the areas by States of the refuges administered by the Biological Surrey. In table $I$ is given a list of these refuges and the chief species for the protection of which each was established, and in tables III and IV are treated the wildlife refuges administerer by the Biological Survey on areas primarily devoted to other uses, chiefly on reservoirs for irrigation projects under the Bureau of Reclamation.

In addition to these areas it is imperative that waterfowl habitat to the extent of approximately $17,000,000$ acres be obtained for the conservation of migratory game and other birds protected under treaty with Great Britain. These land and water areas for the waterfowl should be in two classes-breeding grounds and feeding and resting grounds. Migratory waterfowl are in a particularly percarious condition and, unless positive action in their behalf is taken without delay, there is little hope of saring some of the native species now in dire straits. These waterfowl areas should be grouped along the major flyways in such way that the birds will find some sanctuary where they can feed and rest in safety, and where they can breed without human interference or molestation by predators. This will inrolve in some eases setting aside Federal lands, but more frequently lands now privately owned should be purchased and placel under Federal administration.

\footnotetext{
I Contributed by the Bureau of Biological Survey.
}

For upland game birds and game mammals, approximately 21,000,000 acres are needed, especially for such big-game animals as mountain sheep and antelope, for which no protection is provided on the national forests except on a few game refuges. The largest antelope herds are now on public domain and private holdings, a fact that must be taken into consideration in making provision for the future of the herds of this most interesting North American mammal. Mountain sheep are in a precarious condition, and certain of the desert ranges, particularly in Nevada and Arizona, should be set aside and developed for the use of these unique animals. For the use of sage hens, prairie chickens, and sharp-tailed grouse, areas on the public domain need also to be designated as wildlife refuges.

Primarily Devoted to Other Major Uses But Designated for Wildlife Sanctuaries: In the majority of cases national forests and national parks provide adequate summer range for the leer, elk, and other big game animals that are found therein. Where there is any deficiency in ability to care for these herds, it is usually from lack of winter forage. This is a pressing problem from the wildlife standpoint, and the lower lying lands along the boundaries of both the forests and the parks shoukl be designated as winter refuges, and forage should be reserved for these big-game animals. For a full discussion of this subject, see contributions by the Forest Service and National Park Service.

State Ounership: While the total acreage in many of the State game refuges is impressire, little of the land is owned by the States inrolved. A few States, notably Pennsylvami, New York, and others in the East, have made some progress toward actnally acquiring land for use as game refuges. In most of the country, however, such areas are either in Federal or private ownership but have been designated as wildlife refuges by legislative authorization or by regulations under State game commissions. Many, howerer, are merely paper refuges, with no control of factors detrimental to the rahuable wildlife they purport to foster. This condition will probably continue to exist until some method can be worked out of removing State game administration from political control. It is almost axiomatic now that whenever a man begins to get some acquaintance with the problems of his State and with methods of handling them, he is thrown out for political reasons, to be succeeded all too frequently by one who is entirely ignorant of the problems he faces. Until this defect is 
corrected, additional State refuges are not so important in the wildlife conservation scheme as would be the better handling of national lands and the development of a consistent Nation-wide policy in game management on Federal lands. There should be a national wildlife program administered and coordinated by a single Federal wildlife agency.

Units Owned by Local Gorernment: Units owned by other local governments are usually too small to be entirely satisfactory as game management units or refuges. Provisions should be made for the exchange or purchase of many local areas, to consolidate them with major holdings of either State or Federal organizations. In a few cases, such as at Lake Merritt, in Oalkland, Calif., a small refuge has been built up into a public attraction of the first order. There is room for many more such well administered loeal units throughout the country.

At present many eities and villages are interested in such a program, and every cncouragement should be offered them to continue sich interest.

\section{Programs of Acquisition; Suggestions for Modification}

The prescnt program of acquisition of migratory-bird refuges by the Federal Government has as its objective two major purposes. The predominant purpose is the aequisition of all possible areas which by reason of their present natural environment will attract migratory birds in the nesting season, or which through development or by restoration to primeral conditions may be made attractive to nesting waterfowl. The sceond objective contemplates the aequisition of more or less extensive resting and feeding areas in the flight lanes used by migratory birds spring and fall, in order that they may be provided with conveniently situated sanctuaries furnishing water, food, and eover in an unmolested cnvironment, protected from both man and predators.

At present, as pointed out by Salyer, ${ }^{2}$ the major efforts are being concentrated on the brecding-ground phase of this migratory-bird-refuge restoration program, but not entircly to the exclusion of efforts for providing resting and feeding grounds. The size of refuges to be so acquired should as a rule be not less than 10,000 acres, but single units where the enrironmental clements are farorable might comprise 50,000 acres or more. An ideal system of refuges would contemplate a series of major projects approximately 300 miles apart in each one of the four major waterfowl flyways described by Lincoln ${ }^{3}$ that extend from the Canadian border to the southern limits of the United States, and in proximity

\footnotetext{
a Salyer, J. C., 11. A Program of Waterfowl Restonatios. C. S. Dent. Agr. Cire. $339,11 \%$., 1934.

z Lincola, F. C. The Waterfowl Flywars of Nortit A urrica. C. S. Dept, Agr. Cire. 342,12 p. illus., 1935.
}

to most, if not all, of these might well be created groups of refuges smaller in size that would be beneficial in the wildlife restoration and conscrvation program.

These are the irleal objectives. Their accomplishment is largely contingent upon the arailability of adequate funds with which to carry them out, but in some parts of the United States, notably where the natural envirommental conditions are most attractive to nesting migratory birds, there should be a radical change in point of view regarling the drainage of lands and the ill-advised use of water through waste and futile reclamation projects. Without some such change in point of ricw, it will not be possible to accomplish fully the objectives of the Biologieal Survey in the matter of an adequate system of refuges. The critical situation of the waterfowl in 1934, following a series of unfaromble years, has been elscwhere presented by Bell and Preble, ${ }^{4}$ their findings having been based on intensive investigations by members of the Biological Survey and cooperating organizations and individual sportsmen and other conservationists.

\section{Integration of Federal And State Policies}

Federal and State Governments should work in close cooperation in dealing with game problems and as far as possible any causes of friction slould be removed and questions of jurisdiction settled. The national forests are the natural reservoirs of most of our large game, especially deel. The Forest Serrice is eharged with the general care of these forests, but the game policy, or lack of policy, of some States in which forests are located may hamper cooperation or completely nullify well rounded forest management, which should encompass all forest resourees-game a : well as timber. For cxample, on many western national forests the grazing of domestic stock is an important industry and may constitute the major use of the land. In places, deer, elk, and other kinds of big game in uneontrolled numbers seriously compete with domestic stock for food, and overbrowsing by both elasses of animals nay be seriously destructire to forest reproduction. In addition, such intensive use results in general watershed denudation, and this greatly accelerates destructive erosion. Obriously the urgent need is the regulation of numbers of both stock and game in aecordance with the food supply, in such way that none of the conflicting interests will be sacrificed. Such regulation is a difficult and complex problem at best, and calls for a comprehensive and sustained plan of wildlife management. In adequate solution of the problem is virtually impossible where dependent upon policies ehanging with State politics.

- Bell, W B., and l'reble, E. A. Stat's of Waterfowl IN 1934. L. S. Dept. Agr. Misc. I'ubl. 210, is P., illus. 1934. 


\section{Encouraging Game Production On Private Lands}

Studies of local needs should be made and food and cover plants developed where required. In many places the restoration of game that has become extinct is neecssary. One measure usually needed in all places is to extend more adequate protection to the wildlife already present.

Edueational programs should be developed, including the use of motion pictures, to acquaint landowners with practical means of producing game and with profitable ways of harvesting the crop. The attitude of the farmer especially has an important bearing in this connection. Farmers should be shown that rabbits, quail, pheasants, and other game, as well as furbearing animals and fishes, have a potential crop value similar in kind to that of any other product of their acres. They should be encouraged to expect a profit through the sale of shooting or trapping rights, commensurate with their efforts to produce game, under regulations fixed by the State.
Planned utilization of land for wildlife development, for game management, and for human enjoyment of large natural wilderness areas is deserving of the interest and active support of all concerned-the land economist, the sportsman and conservationist, and the farmer. The policies in such a program should be such as not to sacrifice human interests, but rather to advance them through better realization of the importance of the wildlife resources and of their function in human economy.

The policies should not give wildlife priority rights everywhere, to the exclusion of other enterprise. They slould, however, recognize clearly that wildlife is entitled to its slare of land and water and to have adequate areas set aside solely for its use and benefit. The time when the best uses are being sought for submarginal private holdings is appropriate for making plans to return a vast acreage to its original and best use-as habitat for wildlife. The need is now so pressing that it deserves a major place in the national land utilization program. 


\section{S E C T I O N I I I}

\section{WI L D I F E M A A G EM ENT IN NATIONAL FORESTS ${ }^{1}$}

\section{Encouraging Game Management On Public Land in Other Use}

Wildlife in Tational Forests: The production and management of wildlife is an important objective in the coordinated management of the national forests to produce the highest economic, scientifie, aesthetic, and recreational values. Management contemplates the production of the largest wildlife population consistent with: (1) Use and needs of other resources, and (2) permanent food supply of animals, birds, and fish.

Wildhe includes all species of game animals (large and small), game birds, fur-bearers (both predatory and herbivorous), nongame birds, and fish. Of all wildlife, big game animals-deer, elk, bear, mountain sheep, and others-are by far the most spectacular. On some national forests, however, small game animals and birds-squirrel, rabbit, grouse, and turkey-are at present far more abundant, and consequently of greater importance than big game.

Although the national forests are the habitat of comparatively large proportions of the total numbers of many of the important wildlife species-particularly in the Western States-distribution of wildlife on the forests is by no means uniform. Some areas are overstocked, others could support larger populations. Each locality presents its own peculiar problems of correlation of uses and interrelation of wildlife species.

Scientific Management of Game on Federal and State Refuges: Despite inadequate basie knowledge, lack of sufficient trained persomncl, and a question as to the legal control over wildlife, the Forest Service aided by the Biological Survey has made a start in scientifie management. On Federal game refuges, notably the Kaibab in Arizona and the Pisgah in North Carolina, the regulation of game populations within reasonable bounds, by means of controlled lunnting, is being practiced. The 283 State game refuges, comprising $21,000,000$ acres on national forests, provide sanctuary and breeding grounds. Forest officers cooperate with the States in the enforcenent of game laws. Fire protection alone is of extreme value in the development and maintenance of adequate wildlife populations. Stream surveys in cooperation with the Bureau of Fisheries and the improvements of habitat in

I Contributed by C. E. lacliford and I. S. Gross of the Forest Service, Depart ment of Agrieulture. accordance with prescribed plans are also underway. Thille wildlife ranges have long been studied by local forest officers and preliminary management plans dereloped, this work is being carried further in cooperation with the Biological Survey, whose trained personnel brings to it the expert adrice so badly needed.

Essentials of Management Program: Two things need to be done: (1) Bring about adequate stocking of all land and water areas on national forests with suitable species; and (2) initiate satisfactory management.

A number of obstacles nust be overeone in the consummation of this program. Of greatest present concern is the inadequacy of the game laws of most States. Existing game laws, almost without exception, have been directed toward preservation rather than sustained production of wildlife. Results rary with character of the laws and their enforcement. Biological relationships are not changed by legal enactments and frequently operate to nullify them. Nodern hunting, fishing, and trapping laws, based upon control of numbers of game killed by localities, are essential to rational management on a sustained production basis.

Western national forests at present include only about 40 percent of the winter range needed to support big-game populations large enough to utilize available summer range. Despite all possible adjustments of range use between wildlife and domestic livestock, this shortage of winter game range constitutes a scrions limitation to increased wildlife populations.

Control of disease and predators constitute fields wherein increasing activity is needed in researeh into basic principles and practical methods of application.

Law enforcement is, and probalbly always will be, an important part of wildlife management. Close cooperation with State game officials, encouragement to the States to pay greater attention to this phase, and, where necessary, increase in Federal enforcenent personnel are indicated.

Cooperation of Forest Service and States.-In order to redeem its responsibility in wildlife managenent, the Forest Service will continue to extend full cooperation to all States willing to join in constructive efforts for sound development and use of this resource. In any case where it is not practicable to proceed on this basis, the Forest Service should assume full anthority and responsibility for wildlife manngenent in the 
national forests. The former course is much to be preferred. Steps necessary to its accomplishment are:

1. Elucational courses in universities and colleges to develop personnel trained in scientific and practical wildlife management as related to forestry.

2. Provision for the employment of an adequate, qualified personnel, both Federal and State.

3. Clear-cut definition of the responsibility for wildlife management on Federal land by Forest Service and State officials.

4. Complete revision of State game laws, based on biological facts rather than political consideration and resting broad general powers in a nonpartisan board or commission.

5. Careful survey of wildife resources, both publicly and privately owned, by competent personnel; development of wildlife management plans.

6. Adequate appropriations for the employment of persomnel necessary to the application of management plans and the extension of research.

\section{Economic and Social Values of Wildlife Areas}

Talue, Extent, and Conditions of Wildlife on Forested Lands: The forested lands of the United States provide the largest part of habitat for most of that remaining wildlife which is important for food, fur, hunting, and aesthetic purposes. In 1929 the number of hunters and fishermen in the United States was placed, by the Senate Committee on Conservation of Wildlife Resources, at 13,000,000, an increase, it is estimated, of 400 percent in a single decade. The total positive national value of all wildlife is estimated (by the Biological Survey) at more than $\$ 1,000,000,000$ annually.

Wildlife has decreased, and is still decreasing, on much of the forest land of our country as a whole." Reasons are obvious: The enormous increase in numbers of hunters, discase, deterioration, or destruction by fire (and otherwise) of forest cover and forage, lack of management on at least four-fifths of the more than $600,000,000$ acres now classed as forest or potential forest land.

Increase of Gume Animals in the National Forests: Contrasted with the general situation the number of game animals on $167,000,000$ acres of national forests presents a different picture. Estimates, based upon observations made by hundreds of forest officers who spend a large part of their time on the game ranges, show an increase of 100 percent between 1921 and 1933 . (See chart showing trends of big game populations 1921-33.)

Double Talue of Ilildlife: Three-fifths of the estimated total wildlife ralue is classed as economic, the remainder recreational. Economic values include serv-

2"Wildide Conservation" S. Rept. No. 1329. 71st Cong., 3d sess. ices of birds, rodents, and other mammals in destruction of insect pests, as well as returns in the form of meat and fur from liunting, fishing, and trapping.

Measurable social or recreational values consist of expenditures for licenses, transportation, and equipment by luunters and tourists. The large intangible benefits derived by more than $31,000,000$ people who annually risit the national forests cannot be adequately estimated in casl values. Hunting, fishing, and nature study attract large numbers of these people.

Contribution of Game to Business Activity: That those who go in search of game contribute in many ways to business activity throughout the country, is shown in the total annual returns of about $\$ 158,000,000$ for hunters' expenditures and $\$ 254,000,000$ of tourist expenditures credited to wildlife attraction. Hunters' expenditures include equipment, arms, and ammunition purchases and, in addition, transportation, lodging, food, guide, and other personal expenses. Tourist expenditures are concerned with all of these except arms and ammunition purchases.

Examples of the value of national forest wildlife may be cited. During the 1933 regulated lunting season in the Kaibab National Forest in Arizona, 932 hunters spent more than $\$ 43,000$ incident to their sport which resulted in bagging $\$ 59$ deer. The arerage hunter spent $\$ 47,40$ percent of which represented subsistence, 25 percent transportation, 15 percent license fees, and 20 percent other expenditures. On the more accessible Sierra National Forest, the records for 1932 show that 1,400 deer were killed by 6,145 hunters, whose average expenditures approximated $\$ 23$ each. The meat obtained by hunting and fishing is a welcome addition to the larder of many local residents, and highly prized by many of the hunters and fishermen who travel considerable distances to enjoy their favorite sport. Trapping fur-bearers provides a cash return for many a family, and, as wildlife management becomes more intensive, will no doubt assume greater importance in connection with the conscious effort of the Forest Service to supply more work for the dependent population on eaclı national forest, by developing all resources so as to secure maximum yields.

Recent studies by the Forest Service show that there are within, and near the national forests, more than 5,000 farms and rauches primarily operated for recreational purposes. A considerable portion of the livelihood of the owners and operators of these ranches is derived from conducting hunting and fishing parties on the national forests. An example of the magnitude of these undertakings is obtained from the 1929 report of the Dude Ranchers' Association. Fifty-one ranches comprising property valued at approximately $\$ 6,250,000$ showed receipts in 1929 of nearly a million and a half dollars. 


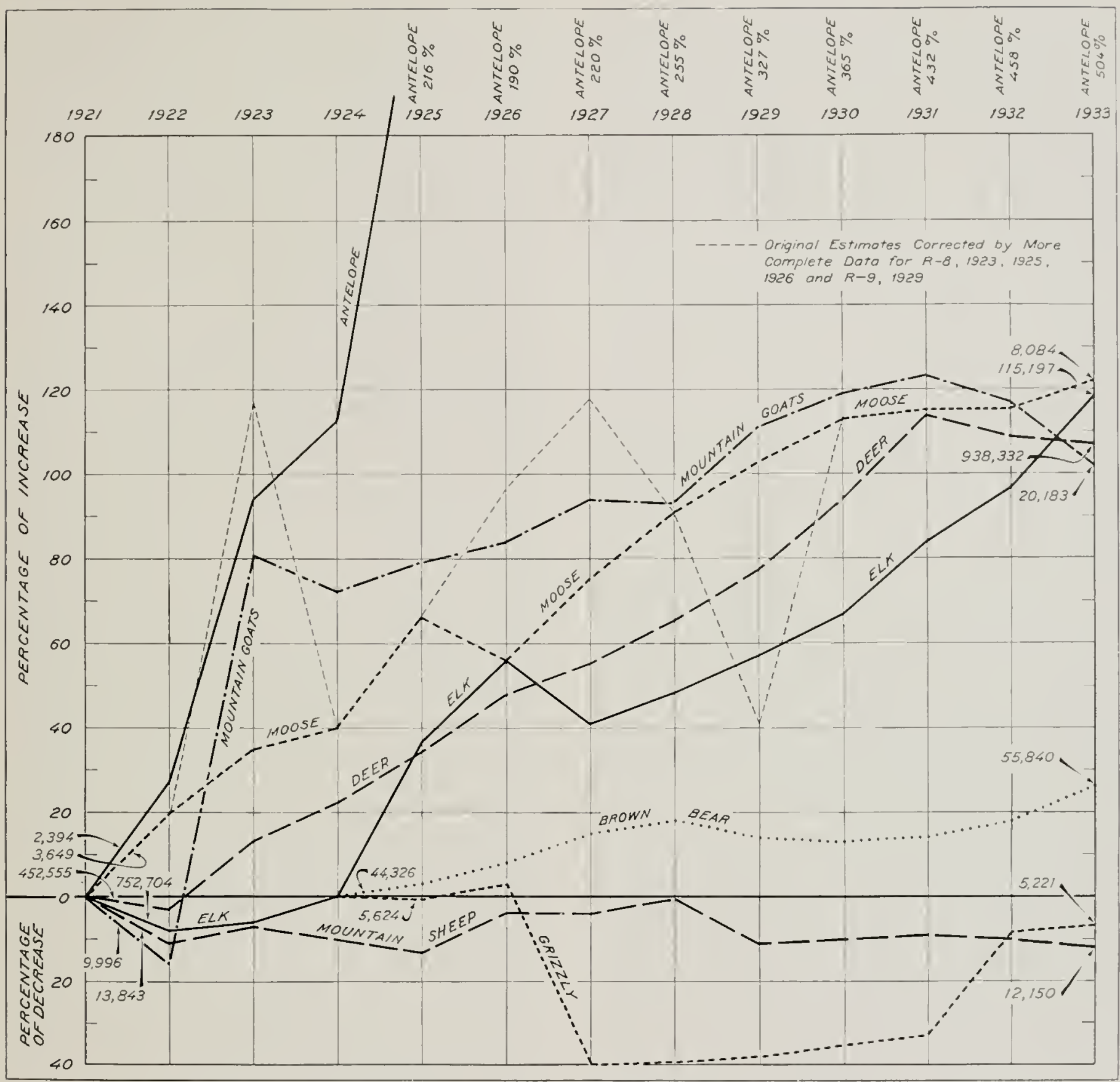

FIGURE I. - INCREASES AND DECREASES IN BIG-GAME ON THE NATIONAL FORESTS 1921-33

Increasing Opportunity for W"ildlife Obsertation: With increasing intensity of wildlife management on the national forests, much greater opportunities will also be created for nature study and wildlife observation. A large proportion of the millions of annual visitors are primarily concerned with getting back to nature for at short period. A cliance to see-and perhaps photograph-a fceding deer, a band of elk, a drumming grouse, or a beaver at work adds zest to the adventure and greatly increases the satisfaction derived from the trip.

\section{Wildlife and Other Land Uses}

Interrelation: Wildlife is directly concerned with practically all other forest-land uses. The full possibilities of such coordination, while apparently great, can be determined only by a most careful study of the biologieal relationships between the fora and famma of each locality. It is desired, however, to set forth some of the signifieant developments in the interrelation of wildlife with other uses of the national forests.

In general it can lee stated that those things necessary for the protection of the forest from fire, as well 
as the application of such measures as are necessary to keep forest land productive, contribute to the welfare of wildlife.

The requirements of game for various types of cover are directly related to silvicultural methods used in cutting, slash disposal, and reforestation. Cutting operations break the forest canopy, and provide food and cover by encouraging the growth of low herbaceous and shrubby regetation, and succulent sprouts highly relished by various wildlife species. On the other hand, game populations so increased may be expected to diminish gradually as the forests mature and the food supply diminishes. Management must seek a proper balance based on the relative importance of each resource in the locality concerned.

Modifications of management plans for both timber and wildlife will of ten be possible. For example, it may be practicable on intensively managed areas to so locate timber cuttings that at all times there will be sufficient feed and shelter, within the cruising range of the wildlife species concerned, to maintain relatively large populations.

Silvicultural Practices and Hildlife: Silvicultural practices on eastern national forests are designed to aid in the production of wildlife as well as timber. This is given definite application on the Allegheny Forest in Pennsylvania. Of the timber trees there, beech is the most important producer of wildlife food, beechnuts being utilized by deer, bear, squirrels, and grouse. Beech, although a valuable timber tree, has a decided tendency to develop a wide-spreading "wolf tree" habit in open stands. It is silviculturally desirable, therefore, to remore defective limby beech on cut-over areas, so that the next stand may be composed of tall, straight, well-formed stems. Following a study of the situation it was decided, however, that it was desirable to reserve an average of four large crowned beech per acre, incident to silvicultural improvement of cut-over areas. This policy has been put into practice as a definite measure for coordinating wildlife with timber production. Serviceberry, a nontimber species, is definitely protected on the Allegheny, because of its value as a producer of wildlife food.

The George Washington National Forest in Virginiu furnishes another example of the effect of silvicultural measures on wildlife. In 100,000 acres, of the MIassanutten Working Circle 1,249 acres of the best sites were subjected to timber stand improvement treatment by the Civilian Conservation Corps in 1933. An average of 37 stems were cut per acre, 70 percent of which were 10 inches or less in diameter. The average acre supported 253 stems after treatment, including such producers of wildife food as hickory, oaks, cucumber, dogwood, black gum, and sumac. The area treated on this working circle is only slightly more than 1 per cent of the total, and the treatment is expected to promote better production of timber without interference with wildlife. As more fundamental data regarding intricate local biological relationships become available, even greater coordination should be possible.

Improvement of Game Conditions an Objective of Forest Planting: The importance of wildlife requirements is also recognized in the national forest planting program. Improvement of game conditions is listed ${ }^{3}$ as one of the objectives in planting. It is the policy to plant first those areas which may be expected to produce the most valuable timber crops; that is, the most productive sites. It is recognized, however, that extensive areas of unbroken coniferons forest-either rirgin stands or maturing plantations-afford ample cover, but little feed for many wildlife species. It is therefore necessary to make definite provision, whenever possible, for supplies of fruits or browse, within or near coniferous plantations. Natural growth may sometimes be utilized for this purpose. The Canaan Mountain planting project of the Monongahela National Forest in West Virginia may be cited. This area of 21,000 acres originally supported dense stands of spruce, hemlock, and hardwoods. Logging and repeated fires wrought colossal changes. Since the tract has come into national forest ownership, protection from fire has resulted in a new growth of hardwoods, with some admixture of conifers, over most of the area. On about 2,500 acres of the most severe burn, however, it has been necessary to reestablish the forest by planting. Red spruce, the native species, was the most logical choice, and was the chief species used. Small cuantities of black cherry, a wildlife food producer, were planted in mixture with the spruce.

Of greater importance to wildlife, however, is the natural growth of mountain ash, viburnum, holly, and other hardwood species. During the establishment of plantations on this project, most of this native hardwood growth was undisturbed. As the plantations mature, it is anticipated that adequate wildlife cover and food will be supplied by the resulting coniferous hardwood mixture.

The planting problem on the Ozark National Forest in Arkansas, on which the predominating type is hardwoods with more or less short-leaf pine in mixture, consists of restocking abandoned old fields scattered throughout the forest. Short-leaf pine is used almost exclusively for planting the old fields. The result will be comparatively small blocks of almost pure conifers, breaking the hardwood cover. Many of these old fields, however, support a scattered stand of persimmon, sassafras, black gum, and other hardwood pro-

\footnotetext{
P. 129-S. National Forest Manual.
} 
ducers of wildife food. These hardwoods, as in the case of those in the Monongahela Forest, may be expected to develop in mixture with the coniferous plantations. The plantations should eventually provide both shelter and subsistence for wildlife.

Some wildlife species, notably ribbits and deer, may become inimical to the establishment and growth of plantations. In the national forests of the Lake States, rabbits have increased to the point where brush areas cannot be successfully planted. Planting must either be limited to more open areas (where rabhit damage is much less severe) or measures undertaken to reduce the rabbit population.

Modification of Wildlife Management: Wildlife management plans must sometimes be modified to accord with plans for timber managenent on specific areas. Relatively inaccessible portions of many national forests must necessarily be handled under extensive forest management, involving less frequent cuttings which cannot be confined to small areas seattered through the entire unit. Under such conditions, wildife management must be directed toward smaller populations, changes in relative number of species, or a fluctuation in populations with character of cover on the various portions of the unit.

Hildlife and Domestic Lirestock on Forest Range: Probably in no other phase of forest-Jand management is the interrelation of wildlife production and other forest uses so apparent as in the use of forest range by wildlife and domestic livestock.

Increase of wildlife on the national forests, requiring in some instances adjustments between game and domestic stock, have sharply focused the attention of foresters and game specialists upon the need for earefully planned and coorclinated use of forest grazing areas.

The outstanding example is on the Kaibab Plateau where an area now complising about 727,000 acres was set aside in 1906 as a Federal game preserve, with deer the principal game species. A measure of protection was afforded by the operations of the United States Biological Survey up to 1923 in destroying predators, and conditions were made firvorable for the deer in other ways. As a result, decr increased until the forage producing capacity of the area was insufficient not only for the deer and domestic stock, but even for the deer alone. Notwithstanding a reduction of domestic livestocks, to a point where competition with deer was at a minimum, the continued incrcase in decr resulted in great damage to the more raluable forage plants and timber reproduction. The productire capacity had been reduced to a degree which would sustain not more than 5 to 10 percent of the game which it was capalle of supporting under proper conditions of nomal use letion las been under way for several years to remedy the situation, and the excessive deer population has been reduced. Restoration of properly balaneed wildife and regetative conditions presents intricate problems of biological relationships and management.

Increasing linowledge of forage requirements of game, as differentiated from the requirements of domestic livestock, offers excellent opportunities for determining a well-balanced relation between numbers of game and livestock. Satisfactory determination of permanent ratios requires additional research and, in the final analysis, should afford the means of obtaining the best development and use of the wildlife resource in its proper relation to timber and other lines of production.

Providing a Proper Balance Between Wildlife Species: The proper balance between the various classes of wildlife is also important. Experience in many places has amply demonstrated that the status of the natural wildlife population may be disturbed by changes of food and corer conditions that farol one or more species over others, or protection by man of certain species from natual enemies. The ultimate goal of land use is the widespread application of principles that will result continuously in proper balanced production of timber, other forest products, and a rariety of wildife.

Competition between wildlife species may at times be a vital factor. In the southwestern part of the Sacramento Mountains in New Mexico, on the Lineoln National Forest, wild turkey are very scarce. They have, in fact, nearly disappeared from that part of the mountains. On this particular range, deer have increased on private holdings and adjacent national forest land. L'se of the range hy deer and donestic stock has so decreased the arailable quantities of the more palatable shrubs that the deer are forced to supplement their usual food with acorns and junipej berries. "This use of mast by deer, together with reduction of other turkey food through overgrazing, destroys the winter forage supply for turkey. In the north end of the Sacramento Mountains, where decr are not plentiful, there are great numbers of turkeys.

The Sitgreaves National Forest, in Arizona, provides another instance of the need for carcful balanec between wildlife species. Elk lave inerensed on the summer range here to such an extent that ther are killing out the willows in high mountain neadows. This, together with overgrazing of vuceas and other plants utilized by elk along the eanyon walls, and trampling of the soil, is resulting in crosion. The delicate relationships between a constant supply of clear water, the development of aquatic life, and shuded pools, so necessay to provide proper habitat for trout in the strentus flowing from this range, are upset hy crosion. Flouds 
scour the streams, wash out plant life, destroy trout shelter and breeding places, and materially reduce the capacity of the streams to produce trout. This serves to illustrate a little-eonsidered relationship between big game animals and fish.

IIinter Range for Game Animals: Game animals liare free access to every acre of the national forests which is suited to them, including the $\$ 2,000,000$ acres of range used by domestic livestock. In stocking these ranges with domestic livestock, it is the object to provide amply for the needs of game during that period of the year that game is dependent upon forest range for feed.

Emplasis should be laid upon that last statement. Generally speaking, the national forests would support during the summer season many times the present numbers of game animals. In the Western States, however, most of the best winter ranges are outside the national forests, generally on private lands on which little if any consideration in given to the welfare of game. This presents one of the most important problems to those interested in big game. Obriously, any expectation that a larger number of game animals can be maintained than is represented by the eapacity of the winter range is based upon a slender reed of hope which fails to recognize realities.

To be more specifie, it is estimated that national forest ranges in Colorado could support during the summer months 300 percent more big game animals than are now present, if protection and mangement were provided on some $10,000,000$ acres of winter range outside the national forests. In this case, as in many others, winter range is the governing or limiting factor in game production. The part which winter range plays in game production might be illustrated by many other specific examples. The Targhce National Forest, in Wyoming, however, is sufficient to slow the relationship between sheep and big game animals. This forest supports more than 200,000 head of domestic sheep and a small number of game animals, yet inspection by grazing experts indieates that its summer range is conservatively used by sheep, and that there is an enormous quantity of food available for game animals. The area is deficient, however, in winter feed for game. Cold and severe winters force the game animals to the lower areas on private lands outside the forest, where they are subjected to shortage of feed and other perils. The exclusion of sheep from the national forest would fail to relieve a condition of this kind.

Grazing of sheep, particularly on western ranges, may conflict with ground nesting game birds, such as grouse, sage hen, and tnrkey. On national forest ranges, however, the nesting habits of game birds have been taken into consideration in the establishment of opening dates for the sheep grazing season. This date has been set sufficiently late in the season so that the eggs have hatched and the chicks have left the nest before shcep are admitted to the range. Management of the domestie animals is so regulated as to avoid a concentration of grazing on any particular area. This method greatly reduces the actual conflict and damage to nests which occurs on areas of heary coneentration of domestic livestock, such as lambing grounds, driveways, and bedding grounds.

Control of Predatory Animals: Predatory animal control is an important factor in wildlife management. This is emphasized by reports for 1932 from field officers, which show that for every deer killed by hunters on the national forests, one and a half deer were killed by predatory animals. This raises the question as to whether game is raised to afford sport or to feed predators. It seems reasonable to assume that the predator may play an important part in assisting in the regulation of numbers of game animals to the eapacity of the range, or may be responsible for a serious decline in the herds.

That sheep grazing is not an important limiting factor in game production can be illustrated by the situation in the eastern and southern regions. These regions have more than $5,000,000$ acres of the best and most natural game range. A total of only 2,600 sheep are grazed on 8 national forests, yet there is a very small game population per acre. About one-fifth of the big game animals on the forests in the Eastern United States are on a Federal game refuge (the Pisgah Refuge), where full protection is accorded under the anthority of the Forest Service. But wildlife on areas outside the game refuge is subjeet to all the perils of a poor regulatory system, including illegal killing and destruetion by dogs.

Fishing Benefited by Forest Management: Fishing in the 60,000 miles of national forest trout streams is also benefited by scientific forest and range management. These measures tend to conserve water supplies and maintain continuous stream flow, so essential to sustain production of satisfactory quantities of game fish.

Fur Bearers in National Forests: The production of sustained wildlife yields on the national forests involves not only game animals, game birds, and fish, but also fur bearers. Among the latter are such carnivores as the mountain lion, lynx, fox, and mink. Careful study of loeal biologieal relationships between fur bearers and both game species and domestic lirestock is one of the pre-requisites to the formulation of wildlife-management plans. Damage must always be weighed against value, and an effort made to secure maximum benefits.

The beaver is an excellent example of a nonpredatory fur bearer. Here again, eomplieated relationships exist. 


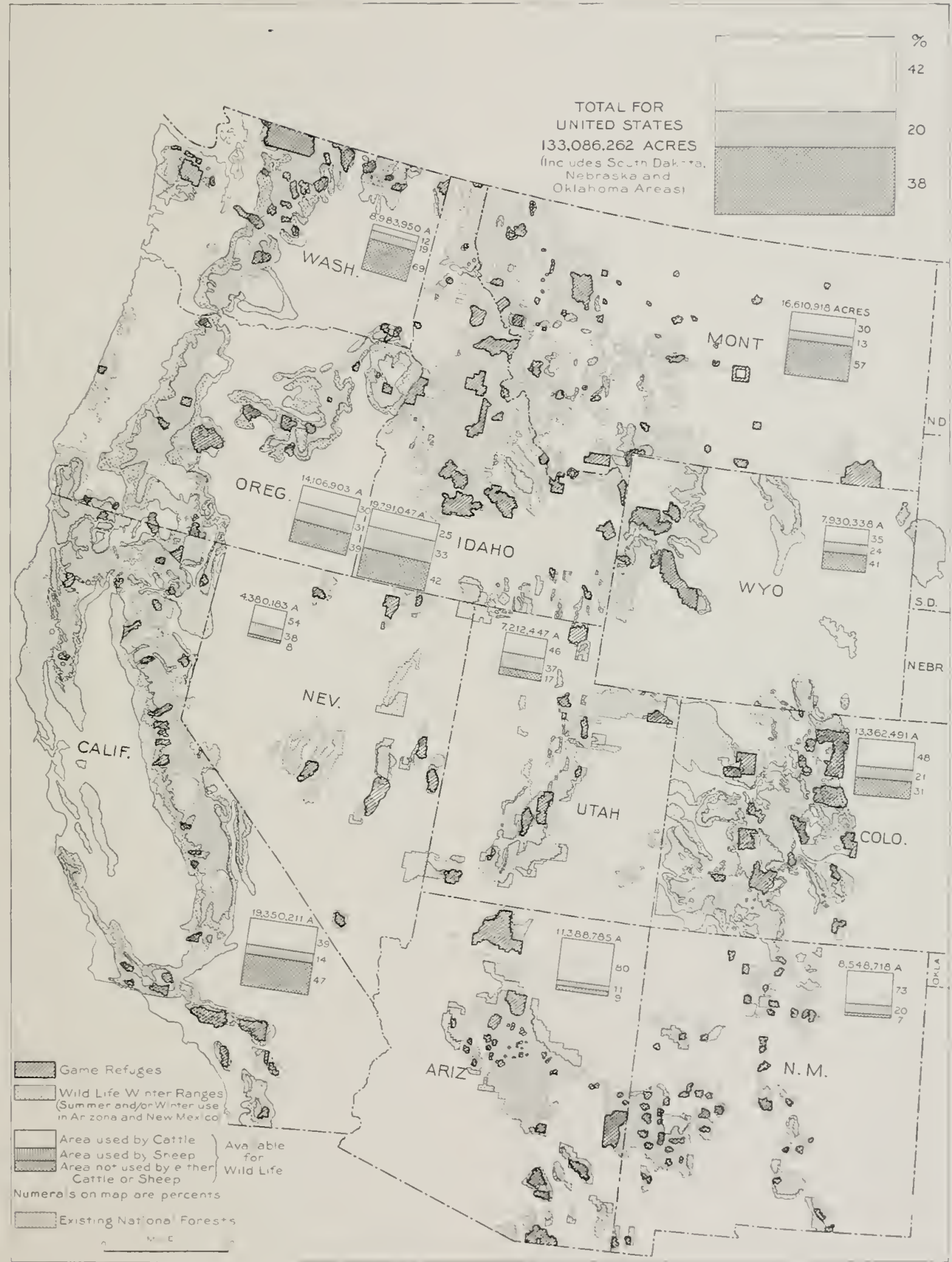

FIGURE 2 - LOCATION OF GAME REFUGES AND WINTER RANGES NEEDED IN CONNECTION WITH NATIONAL FORESTS, AND PERCENTAGES OF NATIONAL FOREST LANDS USED BY CATTLE AND SHEEP 
Studies on a number of national forests show that beaver are of great value in watershed control. Beaver dams create small ponds and lakes, impounding and conserving the water. An instance in which this produced measurable economic value was noted on the Gunnison Forest in Colorado. In 1924, the water supply for the Minnesota Reservoir ran low and sufficient water was not available for late irrigation. Fourteen large beaver ponds on the streams above were tapped, filling the reservoir. This supply, which had been stored by the bearer, practically saved the fruit crop on every orchard dependent upon this irrigation project for water. The fruit growers valued this emergency water supply at $\$ 15,000$, an average of more than $\$ 1,000$ for each of the dams tapped.

Control and Regulation of the Beaver Necessary: Beaver are responsible, however, for considerable damage to some irrigation projects, by diverting the flow from ditches and flooding fields. Damage also occurs by the flooding of roads, trails, and railroad embankments. Under such conditions, careful control is necessary.

Forage conditions may be improved by beaver dams which check the flow of rapid streams, spreading ont the water and resulting in greater production of willows and succulent grasses. The beaver population must be regulated, however, since natural increase in numbers frequently results in shortage of aspen and other bearer feed. Cases are on record where shortage of food has resulted in wholesale migration of beaver to other watersheds. In other cases, unregulated trapping of heaver has also resulted in virtual elimination of the species on certain streams. The result of either forced migration or destruction by man are the same. The dams are washed out, erosion occurs, stream flow tends to revert to altemating floods and low stages. The solution to such problems involves maintenance of the beaver population on eacb stream at such a level that the maximum benefits will accrue without undue damage to other uses, and withm the limits of available feed. This may be accomplished by regulated trapping.

Beaver dams on cold, rapidly flowing streams usually improve fishing conditions by providing deep backwaters, suitable spawning grounds, and increased feed. On the contrary, the results of beaver dams on sluggish streams may be detrimental to game fish. For example, water in the dams may reach a higher temperature than can be tolerated by the fish, or decaying vegetable matter may create an undesirable habitat.

Use of $W^{\top}$ ater Areas: That the protection and propagation of wildlife species can be properly coordinated with other land uses is further indicated in the relationship of the use of water arens by waterfowl to the use by recreationists and domestic livestock. On some of the lakes on national forest areas where feed conditions are suitable to resting and breeding grounds for migra- tory birds, the shore line generally used for nesting purposes is also occupied by fishermen. Notable instances have occurred where, due to increase in recreational use, migratory birds have been deprived of the nesting grounds along the shores of the lakes. This situation may be easily corrected by the prohibition of fishing on those portions of the lake shore best adapted to waterfowl use, and the posting of such areas against trespass.

The same situation applies where many of these lakes afford the only available watering place for domestic livestock. If the livestock is allowed to concentrate around the shores, the lakes are no longer valuable for wildlife purposes except as resting grounds. If, however, the livestock is definitely restricted to watering at certain portions of the lake, the needs of both are met.

Conclusions: The foregoing discussion and examples of the possibilities and limitations of the association and production of wildlife with other land uses point to a number of conclusions.

1. Wildlife production may be definitely coordinated with all other land uses on the national forests.

2. Many biological relationships, basic to complete coordination, remain to be investigated.

3. Coordination must be applied locally. Dominant use may vary within regions, national forests, drainages, or smaller units.

4. Sustained production of wildlife implies regulated use, necessary to control populations within available food supplies, and, in varying degree, within other land use requirements.

5. Adjustments between uses, involving priority ratings, must be expressed in integrated plans for management of wildlife and other national forest resources.

\section{Areas Suitable Only for Refuges}

Since the refuge idea must be fitted into the proper place in the management plan as a whole, permanent dedication of any area to a wildlife refuge has been found undesirable on the national forests, except as a means of perpetuating an almost extinct species or where the area will serve no other useful purpose. A refuge may provide excellent cover for breeding or other purposes when established, but, because of changing biological relationships, may not be satisfactory for that purpose on a permanent basis. The system of management must be sufficiently flexible to permit the closing of areas to hunting and fishing, and the establishment of other restrictive measures when and where conditions justify such action. It will probably always be necessary to reserve certain areas to meet the purpose contemplated by the refuge idea, but in the absence of complete management plans for 
all areas there are no data available to inclicate the percentage of land which will be primarily devoted to that purpose.

Within the national forests, there are approximately $\$, 000,000$ acres of land classed as "barren" on which some forms of wildlife are found. This area, so far as can be seen, will serve no other purpose than the production of wildlife. While its classification would indicate lack of regetative cover, this is not entirely true since within the cracks and crevices and along the narrow ledges on the faces of almost perpendicular cliffs, and on other inaccessible areas there is ample food for the species of wildlife inhabiting such localities, such as mountain goats, mountain sheep, and ptarmigan.

In addition, there are within the national forests some 10,000,000 acres of "brush land", much of which will be permanently useful only for watershed protection and wildlife production.

\section{Areas Specially Adapted to Wildlife}

The areas of private land and public domain listed in table II, as needed for additions to national forests in regions 1 to 10 , inclusive, are vital to wilúlife management on the western national forests. They are an integral part of the winter range for many of the big game herds which depend upon national forest ranges for subsistence during the summer months. Heavy snows and severe cold drive elk and deer from the high summer ranges to the lower country, where climatic conditions are more farorable and food may be obtained during the winter.

The capacity of the national forests to produce sustained crops of big game animals is very definitely limited by the availability of winter range. Under present conditions of ownership and use, that portion of winter range in private ownership $(6,000,000$ acres $)$ and in the public domain $(14,000,000$ acres $)$, within and adjacent to national forests, is not capable of supplying forage adequate to maintain wildlife populations as large as can be supported by national forest summer ranges.

These areas, totaling $20,000,000$ acres, should be added to the national forests, and other uses, chiefly grazing by domestic livestock, should be sufficiently curtailed to allow the big game herds to increase to a size comparable with the carrying capacity of the high national forest summer ranges.

\section{Areas Available for Wildlife}

All national forest land is now and nnay in the future be employed for the production of some form of wildlife in conjunction with other uses. The following tabulation shows the extent of these areas, by national forest regions.
TAnLE I.-- Jixtent of mational forest area which is available for willlife use

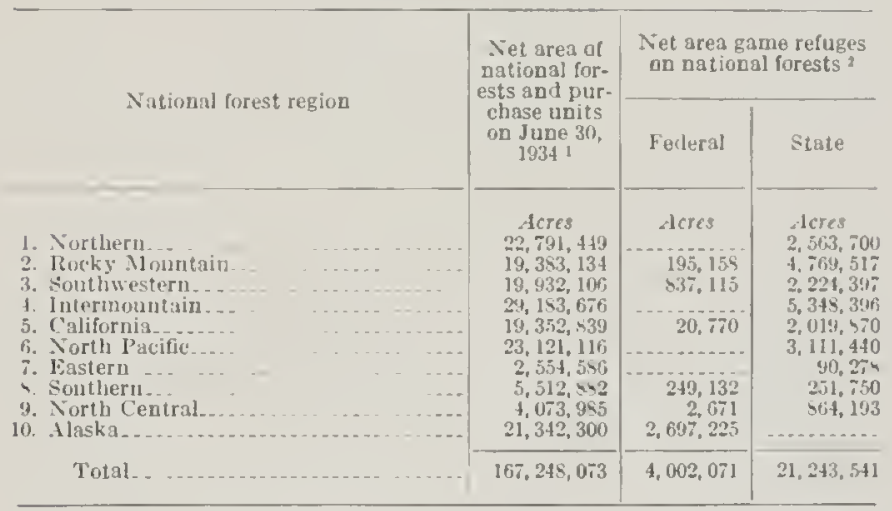

1 Includes land approred for purchase under the Weeks and Clarke-Mc.Nary laws.

2 Included in net area national forests and purchase units.

The 167,000,000 acres of national forest land, located in 33 States, Alaska, and Puerto Rico, is all arailable for wildlife. All of this land, except the 25,000,000 acres of Federal and State game refuges, is open for hunting and fishing, subject to the laws of the several States. Hunting is also permitted on some of the Federal refuges, under special regulations.

Almost $3,000,000$ acres have been closed to use by domestic livestock, in the interest of wildlife production. These areas, however, may be used for other purposes, such as timber production and recreation. This illustrates the policy of correlated land uses, a principle which can be applied in safeguarding the wildlife resource. Strictly speaking, therefore, there are no areas in the national forests devoted exclusively to wildlife, but future studies may reveal the necessity for dedicating areas to only one use.

\section{Needed Additions to Forests}

The Forest Service believes that, in the interests of the production and management of wildlife, three classes of additions to the national forests are essential: (1) Completion of the purchase program in the East, within purchase units approred by the National Forest Reservation Commission; (2) purchase of certain essential areas of winter game range within and adjacent to the national forests; and (3) transfer of certain areas of winter game range within the public domain to adjacent national forests. These recommended additions are shown in table II.

Of the $34,000,000$ acres needed for additions to the national forests, all but $14,000,000$ acres of public domain will, if acquired, be deroted to wildhife in association with other uses. The public-domain lands are urgently needed for specialized winter range use by biggame animals summering on the national forests. These lands, if added to the national forests, will be so administered that the winter range for big-game animals, chiefly elk and deer, will be greatly enlarged 
TABLE II.-Nceded additions to the national forests for production and management of wildlife

\begin{tabular}{|c|c|c|c|c|}
\hline \multirow{2}{*}{ National forest region } & \multirow{2}{*}{$\begin{array}{l}\text { Areas needed } \\
\text { to complete } \\
\text { purchase } \\
\text { program on } \\
\text { approved } \\
\text { purchase } \\
\text { uoits }\end{array}$} & \multicolumn{2}{|c|}{$\begin{array}{l}\text { Areas of winter game } \\
\text { range needed for ad- } \\
\text { ditions to national } \\
\text { forests }\end{array}$} & \multirow{2}{*}{$\begin{array}{c}\text { Total } \\
\text { needed } \\
\text { 8dditions } \\
\text { to national } \\
\text { forests }\end{array}$} \\
\hline & & $\begin{array}{l}\text { Private } \\
\text { laod }\end{array}$ & $\begin{array}{c}\text { Public } \\
\text { domain }\end{array}$ & \\
\hline $\begin{array}{l}\text { 1. Northern } \\
\text { 2. Rocky Mountain } \\
\text { 3. Soutbrestern } \\
\text { 4. Intermountain } \\
\text { 5. Californis } \\
\text { 6. Northwestern } \\
\text { 7. Eastern } \\
\text { 8. Southern } \\
\text { 9. North Central } \\
\text { 10. Alaska. }\end{array}$ & $\begin{array}{c}\text { Acres } \\
\\
3,042,924 \\
6,504,702 \\
4,115,433\end{array}$ & $\begin{array}{c}\text { Acres } \\
471,893 \\
3,482,535 \\
868,491 \\
451,380 \\
385,800 \\
407,080\end{array}$ & \begin{tabular}{c} 
Acres \\
123,732 \\
$5,925,460$ \\
$1,367,000$ \\
$4,125,329$ \\
$1,219,093$ \\
$1,431,000$ \\
\hdashline
\end{tabular} & $\begin{array}{l}\text { Acres } \\
595,625 \\
9,407,995 \\
1,367,000 \\
4,993,820 \\
1,670,473 \\
1,816,900 \\
3,042,924 \\
6,504,702 \\
4,522,513 \\
\ldots \ldots . . . . . . ~\end{array}$ \\
\hline Total .... & $13,663,059$ & $6,067,179$ & $14,191,614$ & $33,921,852$ \\
\hline
\end{tabular}

and improred. (See map showing winter range and game-refuge areas, fig. 2.)

\section{Privately Owned Land As a Habitat for Wildlife}

Two classes of land are of interest to the Forest Service in counection with the discussion of the use of private lands for the production of wildife: (1) Privately owned lands intermingled with national forest lands, and (2) privately owned lands intermingled with the public domain. Table II hists the areas in class (1).

This 37,000,000 acres of privately owned land within the exterior boundaries of national forests and purchase units includes the $19,000,000$ acres listed in columns 1 and 2 of table no. II as land needed for additions to the national forests. The remaining $18,000,000$ acres will largely remain in prirate ownership. These lands are, by and large, of similar value and inportance in wildlife production as are adjacent national forest lands. That is, on these lands wildlife may be cooldinated with other private land uses, such as grazing, agriculture, timber production, mining,
TABLE III.-Privately owned lands within national forest and purchase unit boundaries

\begin{tabular}{|c|c|c|c|}
\hline National forest regioo & $\begin{array}{l}\text { Lands within } \\
\text { national } \\
\text { forest and } \\
\text { purchase unit } \\
\text { boundaries, } \\
\text { in prirate } \\
\text { ownership as } \\
\text { of June } 3,1934\end{array}$ & National forest region & $\begin{array}{l}\text { Lauds within } \\
\text { national } \\
\text { forest and } \\
\text { purchase unit } \\
\text { boundaries, } \\
\text { in prirate } \\
\text { ownership as } \\
\text { of June } 3,1934 .\end{array}$ \\
\hline \multirow[t]{2}{*}{$\begin{array}{l}\text { 1. Northern } \\
\text { 2. Rocky Mountain } \\
\text { 3. Southwestern } \\
\text { 4. Intermouotain....... } \\
\text { 5. California } \\
\text { 6. Northwestern........ }\end{array}$} & \multirow[t]{2}{*}{$\begin{array}{l}\text { Acres } \\
3,768,837 \\
1,831,473 \\
2,085,575 \\
1,594,189 \\
4,857,503 \\
3,972,889\end{array}$} & \multirow[t]{2}{*}{ 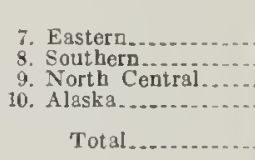 } & $\begin{array}{r}\text { Icres } \\
4,112,912 \\
8,455,279 \\
6,546,515 \\
54,633\end{array}$ \\
\hline & & & $37,309,805$ \\
\hline
\end{tabular}

and recreation. The degree to which these intermingled private lands will produce wildife is dependent upon the emphasis placed by the owners on this use as compared with other uses, and upon the degree of control or wildlife managenent exercised thereon.

Within western game langes, but outside national forest boundaries, there is an estimated total of 55,000,000 acres of land, of which $13,000,000$ acres is public domain on which the wildlife use should be considered of high priority. An additional $8,000,000$ acres of public domain is less important for wildlife usages, but necessary to a full coordination of uses both inside and outside national forests.

The situation with respect to this $55,000,003$ acres of intermingled private and public domain lands is quite analogous, in at least one respect, to the $167,000,000$ acres of national forests, with $37,000,000$ acres of intermingled private holdings. The $55,000,000$ acres is largely suited to the production of wildlife, in coordination with other land uses. A high degree of integration of uses, fully coordinated and sustained long-time programs, and definite and decisive execution of plans are necessary to bring about complete derelopnent and utilization of the wildlife resources on these lands. 


